\title{
Antiseptics as adjuncts to scaling and root planing in the treatment of periodontitis: a systematic literature review
}

Egle Ramanauskaite ${ }^{*}$ (ID and Vita Machiulskiene

\begin{abstract}
Background: Periodontitis is microbially-associated, host-mediated inflammatory condition that results in loss of periodontal attachment. The goals of periodontal therapy include arresting the disease progression, establishing healthy, stable, maintainable periodontal conditions. A fundamental strategy of treating periodontitis is scaling and root planning (SRP), however its efficacy may be restricted in areas inaccessible for mechanical instrumentation. As periodontitis is infectious in nature, it might be helpful to use additional antimicrobial adjuncts, in order to eliminate or inactivate pathogenic microflora. The aim of this study is to evaluate the current evidence regarding the potential clinical benefits of using additional antiseptics for SRP in nonsurgical periodontal therapy.

Methods: An electronic literature search was conducted in the MEDLINE (Ovid) and Cohrane Central Register of Controlled Trials (CENTRAL) databases for articles published between January 1, 2000 and September 22, 2019. Randomized controlled clinical trials in English that compare the effectiveness of one or more antiseptic agents as adjuncts to SRP with a follow-up of $\geq 6$ months were included. A meta-analysis using the random-effects model was performed on the selected qualifying articles.

Results: The search resulted in 12 articles that met the inclusion criteria. Based on the vehicle employed to deliver the antiseptic agent, studies were divided into adjunctive sustained-release antiseptics (gels, chips and varnish) and adjunctive irrigation with antiseptics. The meta-analysis demonstrated significant improvements in probing depth (PD) reduction $(p=0.001)$, clinical attachment level (CAL) gain $(p=0.001)$, and bleeding on probing (BOP) values $(p=0.001)$ following the adjunctive subgingival application of sustained-release antiseptics. Additional subgingival irrigation with antiseptics failed to show significant improvements in PD $(p=0.321)$, CAL $(p=0.7568)$, or BOP values ( $p=0.3549)$ over SRP alone.
\end{abstract}

Conclusions: Adjunctive subgingivally delivered antiseptics with a sustained-release delivery have significant clinical benefits compared to SRP alone.

Keywords: Periodontitis, Antiseptics, Treatment, Review

\footnotetext{
* Correspondence: egle.ramanauskaite@lsmuni.lt

Clinic of Dental and Oral Diseases, Faculty of Dentistry, Lithuanian University

of Health Sciences, Eiveniu 2, 5009 Kaunas, Lithuania
}

(c) The Author(s). 2020 Open Access This article is licensed under a Creative Commons Attribution 4.0 International License, which permits use, sharing, adaptation, distribution and reproduction in any medium or format, as long as you give appropriate credit to the original author(s) and the source, provide a link to the Creative Commons licence, and indicate if changes were made. The images or other third party material in this article are included in the article's Creative Commons licence, unless indicated otherwise in a credit line to the material. If material is not included in the article's Creative Commons licence and your intended use is not permitted by statutory regulation or exceeds the permitted use, you will need to obtain permission directly from the copyright holder. To view a copy of this licence, visit http://creativecommons.org/licenses/by/4.0/ The Creative Commons Public Domain Dedication waiver (http://creativecommons.org/publicdomain/zero/1.0/) applies to the data made available in this article, unless otherwise stated in a credit line to the data. 


\section{Background}

Periodontitis is a chronic multifactorial inflammatory disease associated with dysbiotic plaque biofilms. It is clinically characterized by progressive attachment and alveolar bone loss [1]. The number of people affected by periodontitis has grown substantially, increasing the global burden of the disease [2].

The 2017 World Workshop on the Classification of Periodontal and Peri-Implant Diseases and Conditions has brought new updates to the previous internationally accepted periodontal disease classification (Armitage 1999 [3]). According to the new classification, the disease phenotypes previously recognized as "chronic" and "aggressive" were grouped under one category, "periodontitis," and further characterized based on a multidimensional staging and grading system $[1,4]$.

Despite the updates, treatment goals remain unchanged: arresting the disease's progression; preserving healthy, stable, and maintainable periodontal conditions; and, if possible, regenerating lost tissues.

According to the cause-related therapy concept, SRP is as a cornerstone of periodontal therapy [5]. Its primary goal is to remove soft and hardened microbial deposits from the pathologically exposed root surfaces [6]. Ideally, periodontal therapy should also reduce or eliminate the pathogenic species that cause and/or sustain periodontal diseases [6].

However, this therapy is technically demanding and has certain limitations. Bacterial plaque cannot be sufficiently eliminated from deep pockets, intrabony defects, or furcation areas. It also depends on the operators' manual skills and on various patient-related factors (e.g., patients' smoking status and systemic diseases). Up to $30 \%$ of the total surface area of subgingivally debrided roots may be covered with residual calculus [7]. Therefore, it is important to use adjunctive antimicrobial chemotherapeutic agents to eliminate or inactivate pathogenic microflora in sites where mechanical instrumentation is invidious.

Table 1 Material and methods of the selected studies: country, study design, periodontal status of included cohort, follow-up, sample size, gender, smoking status, age and tested product

\begin{tabular}{|c|c|c|c|c|c|c|c|c|}
\hline Study & Country & $\begin{array}{l}\text { Study } \\
\text { design }\end{array}$ & Periodontal status & $\begin{array}{l}\text { Follow- } \\
\text { up }\end{array}$ & $\begin{array}{l}\text { Number, } \\
\text { gender }\end{array}$ & Smokers & $\begin{array}{l}\text { Mean } \\
\text { (range) age }\end{array}$ & Product tested \\
\hline $\begin{array}{l}\text { Bizzarro S. et al., } 2017 \\
\text { [13] }\end{array}$ & Holland & Parallel RCT & $C P$ & $\begin{array}{l}12 \\
\text { months }\end{array}$ & $\begin{array}{l}56(36 \mathrm{M} \\
20 \mathrm{~F})\end{array}$ & Included & $47.8 \pm 9.3$ & $0,5 \% \mathrm{NaOCl}$ solution \\
\hline $\begin{array}{l}\text { Kanoriya D. et al., } 2017 \\
\text { [14] }\end{array}$ & India & Parallel RCT & $\mathrm{CP}$ & $\begin{array}{l}6 \\
\text { months }\end{array}$ & $42(N R)$ & Excluded & $22-55$ & $0,75 \%$ boric acid gel \\
\hline $\begin{array}{l}\text { Denez E.M. et al., } 2016 \\
\text { [14] }\end{array}$ & Belgium & $\begin{array}{l}\text { Split-mouth } \\
\text { RCT }\end{array}$ & $\begin{array}{l}\text { Moderate-Severe } \\
\mathrm{CP}\end{array}$ & $\begin{array}{l}6 \\
\text { months }\end{array}$ & $28(N R)$ & Excluded & $45 \pm 9.7$ & 10\% PVI solution \\
\hline $\begin{array}{l}\text { Matesanz P. et al., } 2013 \\
\text { [20] }\end{array}$ & Spain & Parallel RCT & PD & $\begin{array}{l}6 \\
\text { months }\end{array}$ & $\begin{array}{l}22(8 \mathrm{M} \\
14 \mathrm{~F})\end{array}$ & Included & 50 & CHX -xanthan gel \\
\hline $\begin{array}{l}\text { Krück C. et al., } 2012 \\
\text { [21] }\end{array}$ & Germany & Parallel RCT & Moderate CP & $\begin{array}{l}12 \\
\text { months }\end{array}$ & $\begin{array}{l}51(22 \mathrm{M} \\
29 \mathrm{~F})\end{array}$ & NR & $51 \pm 11$ & $\begin{array}{l}0,12 \mathrm{CHX} \text { solution, } 7,5 \% \\
\text { PVI solution }\end{array}$ \\
\hline $\begin{array}{l}\text { Sakellari D. et al., } 2010 \\
\text { [15] }\end{array}$ & Greece & Parallel RCT & $\mathrm{CP}$ & $\begin{array}{l}6 \\
\text { months }\end{array}$ & $\begin{array}{l}56(25 \mathrm{M} \\
25 \mathrm{~F})\end{array}$ & Included & $36-75$ & CHX chip \\
\hline $\begin{array}{l}\text { Paolantonio M. et al., } \\
2009 \text { [22] }\end{array}$ & Italy & $\begin{array}{l}\text { Split-mouth } \\
\text { RCT }\end{array}$ & $\begin{array}{l}\text { Moderate - } \\
\text { advanced CP }\end{array}$ & $\begin{array}{l}6 \\
\text { months }\end{array}$ & $\begin{array}{l}98(39 \mathrm{M} \\
59 \mathrm{~F})\end{array}$ & Excluded & $24-58$ & CHX-xanthan gel \\
\hline $\begin{array}{l}\text { Paolantonio M. et al., } \\
2008 \text { [23] }\end{array}$ & Italy & $\begin{array}{l}\text { Split-mouth } \\
\text { RCT }\end{array}$ & $\begin{array}{l}\text { Moderate - } \\
\text { advanced CP }\end{array}$ & $\begin{array}{l}6 \\
\text { months }\end{array}$ & $\begin{array}{l}82(33 \mathrm{M} \\
49 F)\end{array}$ & Excluded & $31-63$ & CHX chip \\
\hline $\begin{array}{l}\text { Paolantonio M. et al., } \\
2008 \text { [24] }\end{array}$ & Italy & $\begin{array}{l}\text { Split-mouth } \\
\text { RCT }\end{array}$ & $\begin{array}{l}\text { C Moderate - } \\
\text { advanced CP }\end{array}$ & $\begin{array}{l}6 \\
\text { months }\end{array}$ & $\begin{array}{l}116(34 \mathrm{M} \\
82 \mathrm{~F})\end{array}$ & Excluded & $33-65$ & CHX chip \\
\hline $\begin{array}{l}\text { Cosyn J. et al., } 2007 \\
\text { [25] }\end{array}$ & Belgium & Parallel RCT & $\mathrm{CP}$ patients & $\begin{array}{l}6 \\
\text { months }\end{array}$ & $\begin{array}{l}33(16 \mathrm{M} \\
17 \mathrm{~F})\end{array}$ & $N R$ & $50.5 \pm 12.5$ & $\mathrm{CHX}$ varnish \\
\hline $\begin{array}{l}\text { Azmak N. et al., } 2002 \\
\text { [26] }\end{array}$ & Turkey & $\begin{array}{l}\text { Split-mouth } \\
\text { RCT }\end{array}$ & Moderate-Severe CP & $\begin{array}{l}6 \\
\text { months }\end{array}$ & 22(NR) & Excluded & $36-62$ & CHX chip \\
\hline $\begin{array}{l}\text { Heasman PA. et al., } \\
2001 \text { [27] }\end{array}$ & $\begin{array}{l}\text { United } \\
\text { Kingdom }\end{array}$ & $\begin{array}{l}\text { Split-mouth } \\
\text { RCT }\end{array}$ & Moderate-Severe CP & $\begin{array}{l}6 \\
\text { months }\end{array}$ & $\begin{array}{l}26(8 \mathrm{M} \\
16 \mathrm{~F})\end{array}$ & Excluded & $42.6 \pm 12.6$ & CHX chip \\
\hline
\end{tabular}

CHX chlorhexidine gluconate

$C P$ chronic periodontitis

$F$ female

$M$ male

$\mathrm{NaOCl}$ sodium hypochlorite

$N R$ not reported

$P D$ periodontal disease

PVI povidone iodine 
Table 2 Material and methods of the selected studies: number of participants at baseline and end of the study, periodontal case definition, treatment protocols, changes in PD, CAL and BOP in test and control groups

\begin{tabular}{|c|c|c|c|c|c|c|c|}
\hline Study & Participants & Periodontal case & Intervention & $\begin{array}{l}\text { PD } \\
\text { changes (mm) } \\
\text { mean } \pm S D\end{array}$ & $\begin{array}{l}\text { CAL } \\
\text { changes }(\mathrm{mm}) \\
\text { mean } \pm S D\end{array}$ & $\begin{array}{l}\text { BOP } \\
\text { changes (\%) } \\
\text { mean } \pm \text { SD }\end{array}$ & Comments \\
\hline \multirow{6}{*}{$\begin{array}{l}\text { Bizzarro S. } \\
\text { et al., } 2017 \\
\text { [13] }\end{array}$} & CONTROL & \multirow{2}{*}{$\begin{array}{l}\geq 2 \text { non-adjacent teeth } \\
\text { interproximal attachment } \\
\text { loss of } \geq 3 \mathrm{~mm} \text {; }\end{array}$} & 1.SRP + S & $\begin{array}{l}\text { Control } 1 \pm \\
0.6 ;\end{array}$ & $\begin{array}{l}\text { Control } 0.6 \pm \\
0.5\end{array}$ & $\begin{array}{l}\text { Control } \\
42.3 \pm 16.9\end{array}$ & \multirow[t]{6}{*}{ NS } \\
\hline & $\begin{array}{l}\text { Baseline } \\
n=29\end{array}$ & & \multirow[t]{5}{*}{$\begin{array}{l}\text { 2. } \mathrm{SRP}+\mathrm{O} \\
5 \% \mathrm{NaOCl}\end{array}$} & \multirow[t]{5}{*}{ Test $0.9 \pm 0.3$} & \multirow[t]{5}{*}{ Test $0.5 \pm 0.5$} & \multirow[t]{5}{*}{$\begin{array}{l}\text { Test } 41 \pm \\
12.6\end{array}$} & \\
\hline & $\begin{array}{l}\text { End of the } \\
\text { study } n= \\
29 ;\end{array}$ & $\begin{array}{l}2 \text { teeth per quadrant } \\
\text { with } P D \geq 5 \mathrm{~mm} \text {, }\end{array}$ & & & & & \\
\hline & TEST & \multirow[t]{3}{*}{$>50 \%$ BOP } & & & & & \\
\hline & $\begin{array}{l}\text { Baseline } \\
n=27\end{array}$ & & & & & & \\
\hline & $\begin{array}{l}\text { End of the } \\
\text { study } n= \\
27 .\end{array}$ & & & & & & \\
\hline \multirow[t]{6}{*}{$\begin{array}{l}\text { Kanoriya D. } \\
\text { et al., } 2017 \\
{[14]}\end{array}$} & CONTROL & \multirow[t]{6}{*}{$\begin{array}{l}\mathrm{PD} \geq 5 \mathrm{~mm} \text { or } \mathrm{CAL} \geq 4 \mathrm{~mm} \\
\text { and vertical bone loss } \geq 3 \mathrm{~mm}\end{array}$} & $\begin{array}{l}\text { Control: } \\
\text { SRP + } \\
\text { placebo } \\
\text { gel; }\end{array}$ & $\begin{array}{l}\text { Control } \\
1.89 \pm 0.45\end{array}$ & $\begin{array}{l}\text { Control 1 } \\
31 \pm 0,82\end{array}$ & - & $\begin{array}{l}\text { Test group showed } \\
\text { significant improvements } \\
\text { in CAL gain and PD } \\
\text { reduction }\end{array}$ \\
\hline & $\begin{array}{l}\text { Baseline } \\
n=21\end{array}$ & & \multirow{5}{*}{$\begin{array}{l}\text { Test: } \\
\text { SRP }+0 \\
75 \% \text { boric } \\
\text { acid gel. }\end{array}$} & \multirow[t]{5}{*}{$\begin{array}{l}\text { Test } 3.15 \pm \\
0.74\end{array}$} & \multirow[t]{5}{*}{$\begin{array}{l}\text { Test } 2.65 \pm \\
0.58\end{array}$} & & \\
\hline & $\begin{array}{l}\text { End of the } \\
\text { study } n= \\
19\end{array}$ & & & & & & \\
\hline & TEST & & & & & & \\
\hline & $\begin{array}{l}\text { Baseline } \\
n=21\end{array}$ & & & & & & \\
\hline & $\begin{array}{l}\text { End of the } \\
\text { study } n= \\
20 .\end{array}$ & & & & & & \\
\hline \multirow[t]{6}{*}{$\begin{array}{l}\text { Denez E.M. } \\
\text { et al., } 2016 \\
\text { [26] }\end{array}$} & CONTROL & \multirow[t]{6}{*}{$\begin{array}{l}\text { At least one pocket in each } \\
\text { quadrant with } P D \geq 4 \mathrm{~mm} \text { and } \\
\mathrm{BOP}(+)\end{array}$} & $\begin{array}{l}\text { Control: } \\
\text { SRP + 0,9\% } \\
\mathrm{NaCl} ;\end{array}$ & $\begin{array}{l}\text { Control } \\
1.92 \pm 0.12\end{array}$ & $\begin{array}{l}\text { Control } \\
1.93 \pm 0.05\end{array}$ & \multirow[t]{6}{*}{ - } & \multirow{6}{*}{$\begin{array}{l}\text { No significant difference } \\
\text { between } \mathrm{NaCl} \text { and } \\
10 \% \mathrm{PVI} \text { in terms of } \\
\text { clinical changes }\end{array}$} \\
\hline & $\begin{array}{l}\text { Baseline } \\
n=28\end{array}$ & & \multirow[t]{5}{*}{$\begin{array}{l}\text { Test: SRP+ } \\
10 \% \mathrm{PVI}\end{array}$} & \multirow[t]{5}{*}{ Test $1.9 \pm 0.3$} & \multirow[t]{5}{*}{$\begin{array}{l}\text { Test } 1.95 \pm \\
0.21\end{array}$} & & \\
\hline & $\begin{array}{l}\text { End of } \\
\text { study } n= \\
\text { 20; }\end{array}$ & & & & & & \\
\hline & TEST & & & & & & \\
\hline & $\begin{array}{l}\text { Baseline } \\
n=28\end{array}$ & & & & & & \\
\hline & $\begin{array}{l}\text { End of } \\
\text { study } n= \\
20 .\end{array}$ & & & & & & \\
\hline \multirow[t]{5}{*}{$\begin{array}{l}\text { Matesanz P. } \\
\text { et al., } 2013 \\
\text { [20] }\end{array}$} & CONTROL & \multirow[t]{4}{*}{$\begin{array}{l}\text { 4-10 pockets with } \\
\mathrm{PD}>4 \mathrm{~mm} \text { and } \mathrm{BOP}(+)\end{array}$} & $\begin{array}{l}\text { Control: } \\
\text { SRP + } \\
\text { placebo } \\
\text { gel; }\end{array}$ & $\begin{array}{l}\text { Control } \\
0.22 \pm 0,46\end{array}$ & $\begin{array}{l}\text { Control } \\
-0.01 \pm 2,1\end{array}$ & $\begin{array}{l}\text { Control } \\
15 \pm 0.4\end{array}$ & $\begin{array}{l}\text { No significant difference } \\
\text { between placebo and } \\
\text { CHX xanthan gel in } \\
\text { terms of clinical changes }\end{array}$ \\
\hline & $\begin{array}{l}\text { Baseline } \\
n=12\end{array}$ & & \multirow{3}{*}{$\begin{array}{l}\text { Test: SRP+ } \\
\text { CHX } \\
\text { xanthan gel }\end{array}$} & \multirow[t]{3}{*}{$\begin{array}{l}\text { Test } 0.32 \pm \\
0.47\end{array}$} & \multirow[t]{3}{*}{ Test $0.3 \pm 0.98$} & \multirow[t]{3}{*}{$\begin{array}{l}\text { Test } 18 \pm \\
0.4\end{array}$} & \\
\hline & $\begin{array}{l}\text { End of } \\
\text { study } n= \\
11\end{array}$ & & & & & & \\
\hline & TEST & & & & & & \\
\hline & Baseline & & & & & & \\
\hline
\end{tabular}


Table 2 Material and methods of the selected studies: number of participants at baseline and end of the study, periodontal case definition, treatment protocols, changes in PD, CAL and BOP in test and control groups (Continued)

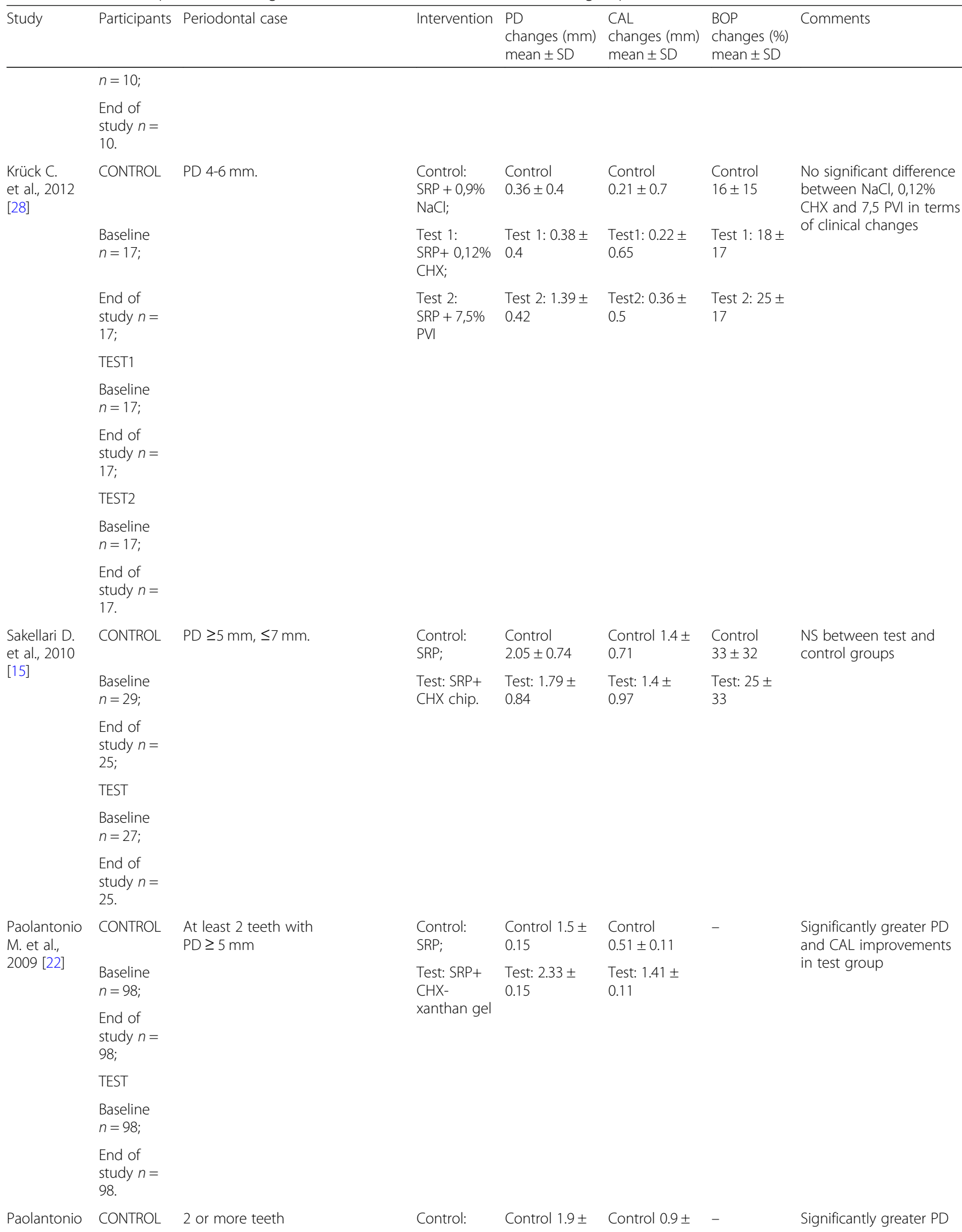

$\begin{array}{lllll}\text { Control: } & \text { Control } & \text { Control } 1.4 \pm & \text { Control } & \text { NS between test and } \\ \text { SRP; } & 2.05 \pm 0.74 & 0.71 & 33 \pm 32 & \text { control groups } \\ \text { Test: SRP+ } & \text { Test: } 1.79 \pm & \text { Test: } 1.4 \pm & \text { Test: } 25 \pm & \\ \text { CHX chip. } & 0.84 & 0.97 & 33 & \end{array}$


Table 2 Material and methods of the selected studies: number of participants at baseline and end of the study, periodontal case definition, treatment protocols, changes in PD, CAL and BOP in test and control groups (Continued)

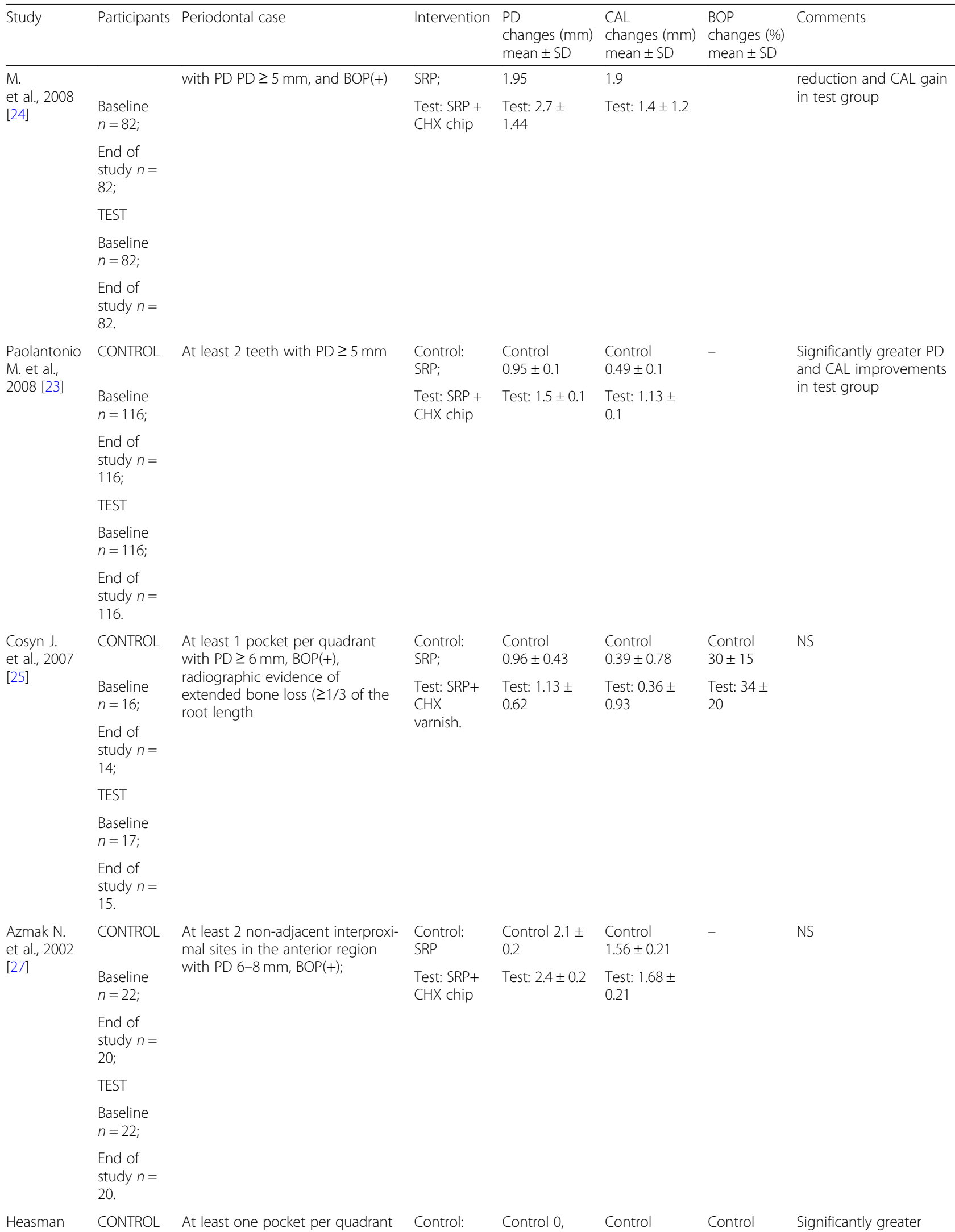

et al., 2008

[24]

Baseline

$n=82$

with PD PD $\geq 5 \mathrm{~mm}$, and $\mathrm{BOP}(+)$

$\begin{array}{lll}\text { SRP; } & 1.95 & 1.9 \\ \text { Test: SRP + } & \text { Test: } 2.7 \pm & \text { Test: } 1.4 \pm 1.2 \\ \text { CHX chip } & 1.44 & \end{array}$

End of

study $n=$

82;

TEST

Baseline

$n=82$;

End of

study $n=$

82.

Paolantonio

M. et al.,

2008 [23]

CONTROL

Baseline

$n=116$;

At least 2 teeth with $P D \geq 5 \mathrm{~mm}$

Control:

Control

Control

SRP;

$0.95 \pm 0.1$

$0.49 \pm 0.1$

Test: SRP + Test: $1.5 \pm 0.1 \quad$ Test: $1.13 \pm$

CHX chip

0.1

End of

study $n=$

116;

TEST

Baseline

$n=116$;

End of

study $n=$

116.

Cosyn J.

et al., 2007

[25]

\section{CONTROL}

At least 1 pocket per quadrant with $\mathrm{PD} \geq 6 \mathrm{~mm}, \mathrm{BOP}(+)$,

radiographic evidence of

Baseline

$n=16$;

bone loss $(\geq 1 / 3$ of the root length

End of

study $n=$

14 ;

TEST

Baseline

$n=17$;

End of

study $n=$

15.

Azmak N.

et al., 2002

[27]

CONTROL

$$
\text { Baseline }
$$

$n=22$;

At least 2 non-adjacent interproximal sites in the anterior region

Control: SRP

Contro :

SRP;

Contro

Test: SRP+

$\mathrm{CHX}$

$0.96 \pm 0.43$

Control

Control

$30 \pm 15$

varnish.

Test: $1.13 \pm$

0.62

$0.39 \pm 0.78$

Test: $34 \pm$

$0.93 \quad 20$

with PD 6-8 mm, BOP(+);

End of

study $n=$

20;

TEST

Baseline

$n=22$;

End of

study $n=$

20.

Test: SRP+ Test: $2.4 \pm 0.2$ Test: $1.68 \pm$ CHX chip

Significantly greater PD and CAL improvements in test group

reduction and CAL gain in test group 
Table 2 Material and methods of the selected studies: number of participants at baseline and end of the study, periodontal case definition, treatment protocols, changes in PD, CAL and BOP in test and control groups (Continued)

\begin{tabular}{|c|c|c|c|c|c|c|c|}
\hline Study & Participants & Periodontal case & Intervention & $\begin{array}{l}\text { PD } \\
\text { changes (mm) } \\
\text { mean } \pm S D\end{array}$ & $\begin{array}{l}\text { CAL } \\
\text { changes (mm) } \\
\text { mean } \pm S D\end{array}$ & $\begin{array}{l}\text { BOP } \\
\text { changes (\%) } \\
\text { mean } \pm S D\end{array}$ & Comments \\
\hline \multirow{6}{*}{$\begin{array}{l}\text { PA. et al., } \\
2001 \text { [21] }\end{array}$} & & \multirow[t]{6}{*}{ with $\mathrm{PD} \geq 5 \mathrm{~mm}, \mathrm{BOP}(+)$} & SRP & $45 \pm 0,13$ & $0.15 \pm 0.09$ & $45 \pm 13$ & \multirow{6}{*}{$\begin{array}{l}\text { improvements in all } \\
\text { clinical parameters in } \\
\text { test group }\end{array}$} \\
\hline & $\begin{array}{l}\text { Baseline } \\
n=26 ;\end{array}$ & & \multirow[t]{5}{*}{$\begin{array}{l}\text { Test: SRP+ } \\
\text { Perio chip }\end{array}$} & \multirow[t]{5}{*}{$\begin{array}{l}\text { Test } 0,78 \pm 0 \\
12\end{array}$} & \multirow[t]{5}{*}{$\begin{array}{l}\text { Test: } 0.43 \pm \\
0.15\end{array}$} & \multirow[t]{5}{*}{$\begin{array}{l}\text { Test: } 78 \pm \\
12\end{array}$} & \\
\hline & $\begin{array}{l}\text { End of } \\
\text { study } n= \\
24 ;\end{array}$ & & & & & & \\
\hline & TEST & & & & & & \\
\hline & $\begin{array}{l}\text { Baseline } \\
n=26\end{array}$ & & & & & & \\
\hline & $\begin{array}{l}\text { End of } \\
\text { study } n 2= \\
24 .\end{array}$ & & & & & & \\
\hline
\end{tabular}

\section{$B O P$ bleeding on probing}

$C A L$ clinical attachment level

$\mathrm{CHX}$ chlorhexidine gluconate

$\mathrm{NaOCl}$ sodium hypochlorite

NS no significant difference between test and control groups

$P D$ probing depth

$P V I$ povidone iodine

SRP scaling and root planing

Recent studies show that periodontal therapy outcomes may be enhanced by using additional systemic $[8$, 9] or local antibiotics [10-12] and antiseptics [13-15].

The emerging global public health issue of bacterial resistance has increased the number of warnings against the unrestricted use of antibiotics to treat periodontal disease [16]. Therefore, systemic antibiotics in periodontitis should be restricted to certain patients under certain periodontal conditions (stages III-IV, grade C, "active" forms, "refractory", and "recurrent" forms of a disease), and they should be used rationally while following optimal protocols [17].

Local antibiotics suffer from several potential problems, including an insufficient spectrum of antimicrobial activity, risks of producing an antibiotic-resistant microbiota, and high acquisition costs [18].

Antiseptics are chemical agents that can destroy microorganisms on live tissues. Antiseptics have some

Table 3 Assesment of the risk of bias

\begin{tabular}{|c|c|c|c|c|c|c|}
\hline Author, year & $\begin{array}{l}\text { Random sequence } \\
\text { generation }\end{array}$ & $\begin{array}{l}\text { Allocation } \\
\text { concealment }\end{array}$ & Blinding & $\begin{array}{l}\text { Incomplete outcome } \\
\text { data }\end{array}$ & $\begin{array}{l}\text { Selective } \\
\text { reporting }\end{array}$ & $\begin{array}{l}\text { Other } \\
\text { bias }\end{array}$ \\
\hline Kanoriya D. et al., 2017 [14] & + & $?$ & + & + & + & + \\
\hline Bizzarro S. et al., 2017 [13] & + & + & + & + & + & + \\
\hline Denez E.M. et al., 2016 [14] & + & - & - & + & + & + \\
\hline Matesanz P. et al., 2013 [20] & + & + & + & + & + & + \\
\hline Krück C. et al., 2012 [21] & - & + & - & + & + & + \\
\hline Sakellari D. et al., 2010 [15] & + & + & + & + & + & + \\
\hline $\begin{array}{l}\text { Paolantonio M. et al., } 2009 \\
\text { [22] }\end{array}$ & + & - & + & + & + & + \\
\hline $\begin{array}{l}\text { Paolantonio M. et al., } 2008 \\
\text { [23] }\end{array}$ & + & - & + & + & + & + \\
\hline $\begin{array}{l}\text { Paolantonio M. et al., } 2008 \\
\text { [24] }\end{array}$ & + & - & + & + & + & + \\
\hline Cosyn J. et al., 2007 [25] & + & - & + & + & + & + \\
\hline Azmak N. et al., 2002 [26] & + & - & - & + & + & + \\
\hline $\begin{array}{l}\text { Heasman PA. et al., } 2001 \\
\text { [27] }\end{array}$ & - & - & - & + & + & + \\
\hline
\end{tabular}

+ = Low risk? = Unclear risk - = High risk 
beneficial properties compared to systemic or local antibiotics [18]. In particular, they have a more extensive activity spectrum. Furthermore, the possibility of resistance formation is reduced by having multiple intracellular targets [18].

The aim of this study is to estimate the current evidence evaluating the potential clinical benefits (in terms of probing depth (PD), bleeding on probing (BOP) reduction and/or clinical attachment level (CAL) gain) of using additional local antiseptics to conventional SRP in nonsurgical periodontal therapy.

\section{Methods}

This systematic analysis report adhered to the Preferred Reporting Items for Systematic Review and MetaAnalyses (PRISMA) statement [19].

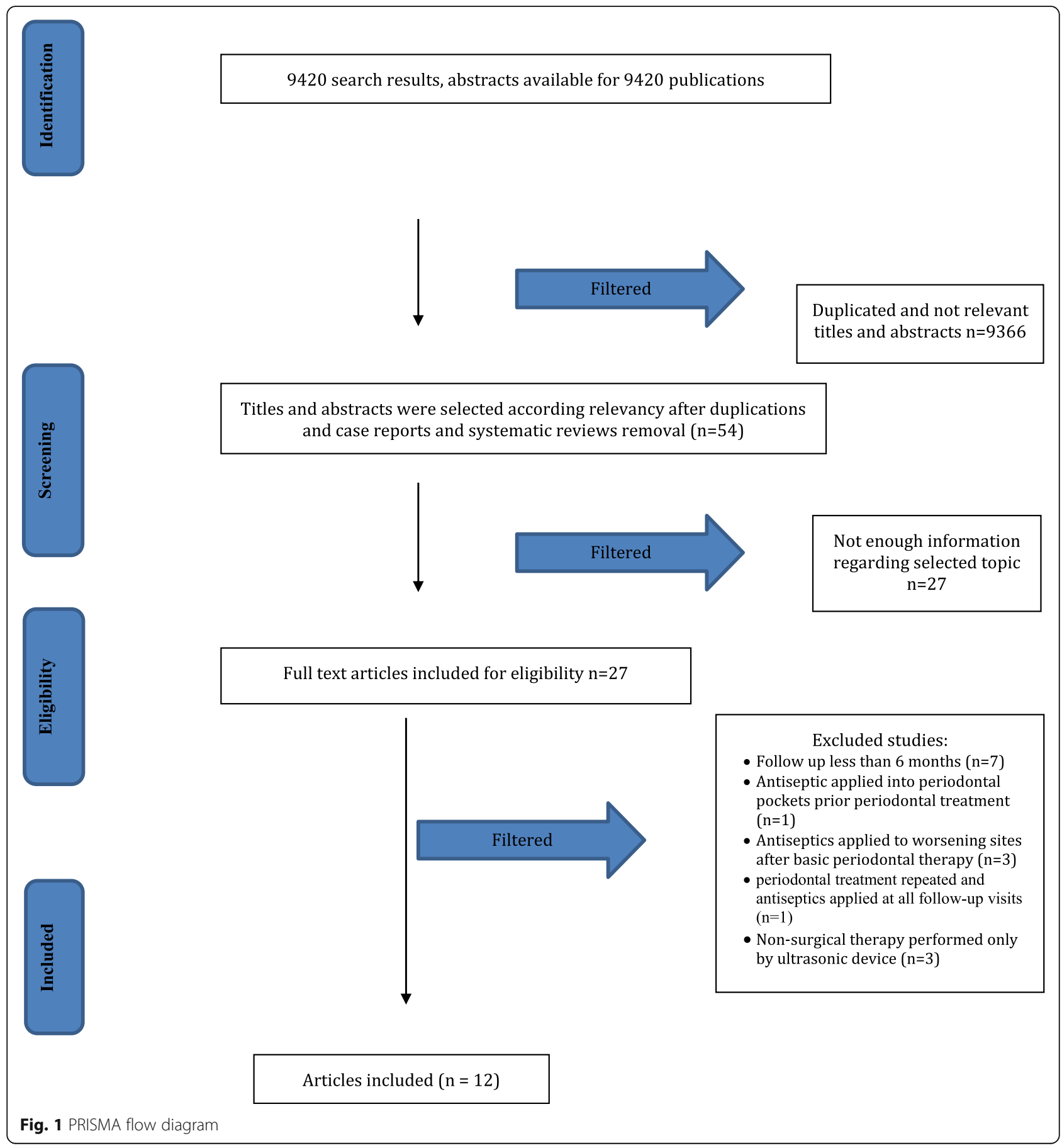




\section{Protocol and registration}

The review was registered in PROSPERO, an international prospective registry of systematic reviews, under number CRD42018086904. The analysis methods and inclusion criteria were specified in advance and documented in a protocol and are accessible through the following link:

https://www.crd.york.ac.uk/prospero/display_record. php?RecordID $=86904$

\section{Focus question}

The following focus question was developed according to the population, intervention, comparison, and outcome (PICO) study design: Does the adjunctive application of antiseptics to SRP have additional clinical benefits compared to SRP alone in treating periodontitis?

Population: Chronic periodontitis patients;

Intervention (test): SRP plus adjunctive antiseptics;

Comparison (control): SRP alone or plus a placebo;

Outcome: The primary outcome variable was the changes in pocket-probing depths (PD); secondary outcome variables included changes in clinical attachment level (CAL) and/or bleeding on probing (BOP).

\section{Information sources}

A systematic electronic literature search was conducted in MEDLINE (Ovid) and Cohrane Central Register of Controlled Trials (CENTRAL) databases. Studies published between January 1, 2000 and September 22, 2019

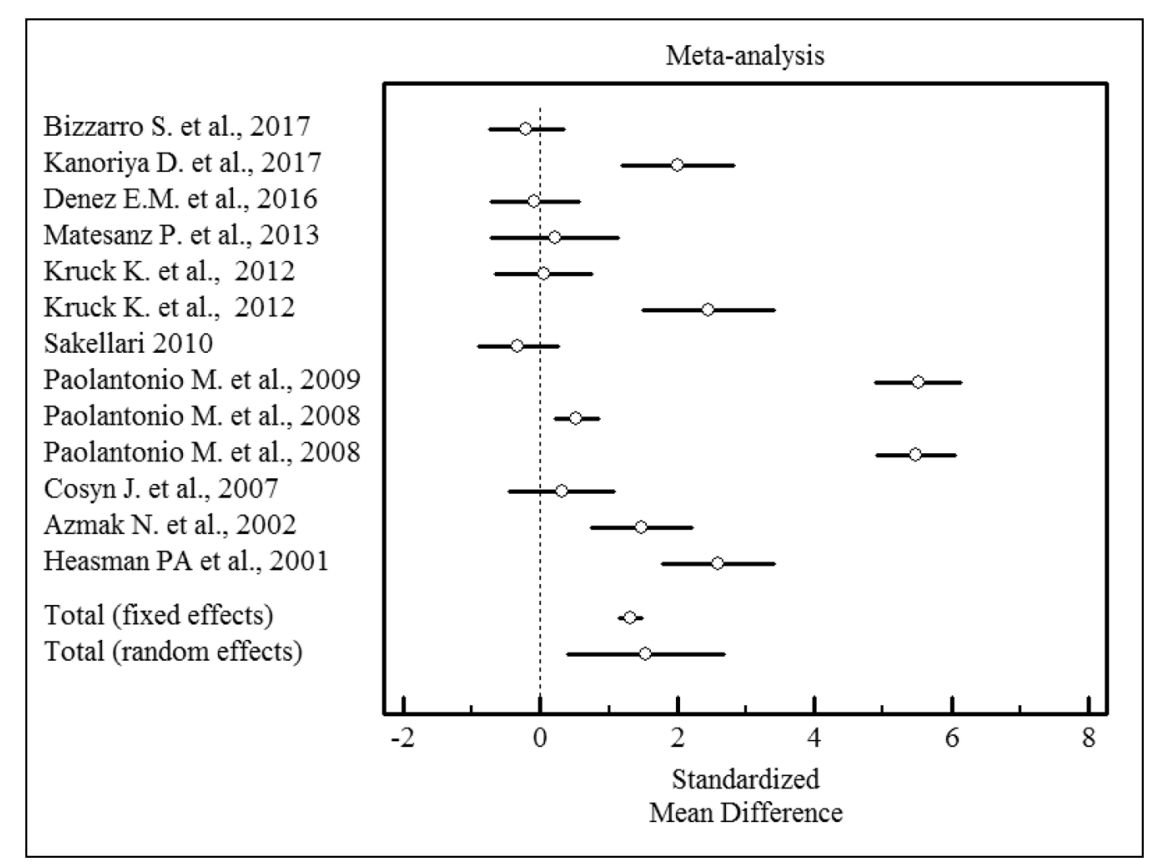

\begin{tabular}{|l|r|r|r|r|r|}
\hline \multicolumn{7}{|c|}{ Q=542.2104, DF= 12, $\mathrm{p}=0.001$} \\
\hline Study & $\mathrm{N} 1$ & $\mathrm{~N} 2$ & Total & SMD & 95\% CI \\
\hline Bizzarro S. et al., 2017 & 27 & 29 & 56 & $-0,206$ & $-0,743$ to 0,332 \\
\hline Kanoriya D. et al., 2017 & 20 & 19 & 39 & 2,003 & 1,193 to 2,813 \\
\hline Denez E.M. et al., 2016 & 20 & 20 & 40 & $-0,0858$ & $-0,726$ to 0,555 \\
\hline Matesanz P. et al., 2013 & 10 & 11 & 21 & 0,207 & $-0,711$ to 1,124 \\
\hline Kruck K. et al., 2012 & 17 & 17 & 34 & 0,0488 & $-0,650$ to 0,748 \\
\hline Kruck K. et al., 2012 & 17 & 17 & 34 & 2,452 & 1,502 to 3,402 \\
\hline Sakellari 2010 & 25 & 25 & 50 & $-0,323$ & $-0,896$ to 0,249 \\
\hline Paolantonio M. et al., 2009 & 98 & 98 & 196 & 5,512 & 4,890 to 6,134 \\
\hline Paolantonio M. et al., 2008 & 82 & 82 & 164 & 0,523 & 0,209 to 0,836 \\
\hline Paolantonio M. et al., 2008 & 116 & 116 & 232 & 5,482 & 4,914 to 6,050 \\
\hline Cosyn J. et al., 2007 & 15 & 14 & 29 & 0,308 & $-0,460$ to 1,075 \\
\hline Azmak N. et al., 2002 & 20 & 20 & 40 & 1,470 & 0,740 to 2,200 \\
\hline Heasman PA et al., 2001 & 24 & 24 & 48 & 2,595 & 1,790 to 3,399 \\
\hline Total (fixed effects) & 491 & 492 & 983 & 1,319 & 1,155 to 1,483 \\
\hline Total (random effects) & 491 & 492 & 983 & 1,536 & 0,402 to 2,670 \\
\hline
\end{tabular}

Fig. 2 Forest plot of odds ratio $(95 \% \mathrm{Cl})$ for probing depth using adjunctive antiseptics 
were searched. An electronic search was supplemented by a manual search of the following journals: International Journal of Periodontics and Restorative Dentistry, Journal of Clinical Periodontology, Journal of Periodontology, and Journal of Periodontal Research.

Scanning of the bibliographies of all publications included into this review was performed for potentially relevant articles.

\section{Search}

The keywords used to search the selected electronic databases included the following Specific Medical Subject Headings (MeSH) terms: ("periodontitis" [Mesh] OR "periodontal disease" [Mesh] OR "chronic periodontitis" [Mesh] AND ("treatment" [Mesh] OR "therapy" [Mesh] OR "antiseptics" [Mesh] OR "scaling and root planning" [Mesh] OR "subgingival irrigation" [Mesh] OR "non-surgical therapy" Mesh]).

\section{Selection of studies}

The resulting articles were revised by two independent reviewers (E.R. and V.M.), based on the inclusion criteria. Disagreements regarding inclusion during the first and second stages of the study selection were resolved by discussion. The agreement level between the reviewers regarding study inclusion was calculated using unweighted $\mathrm{k}$ statistics.

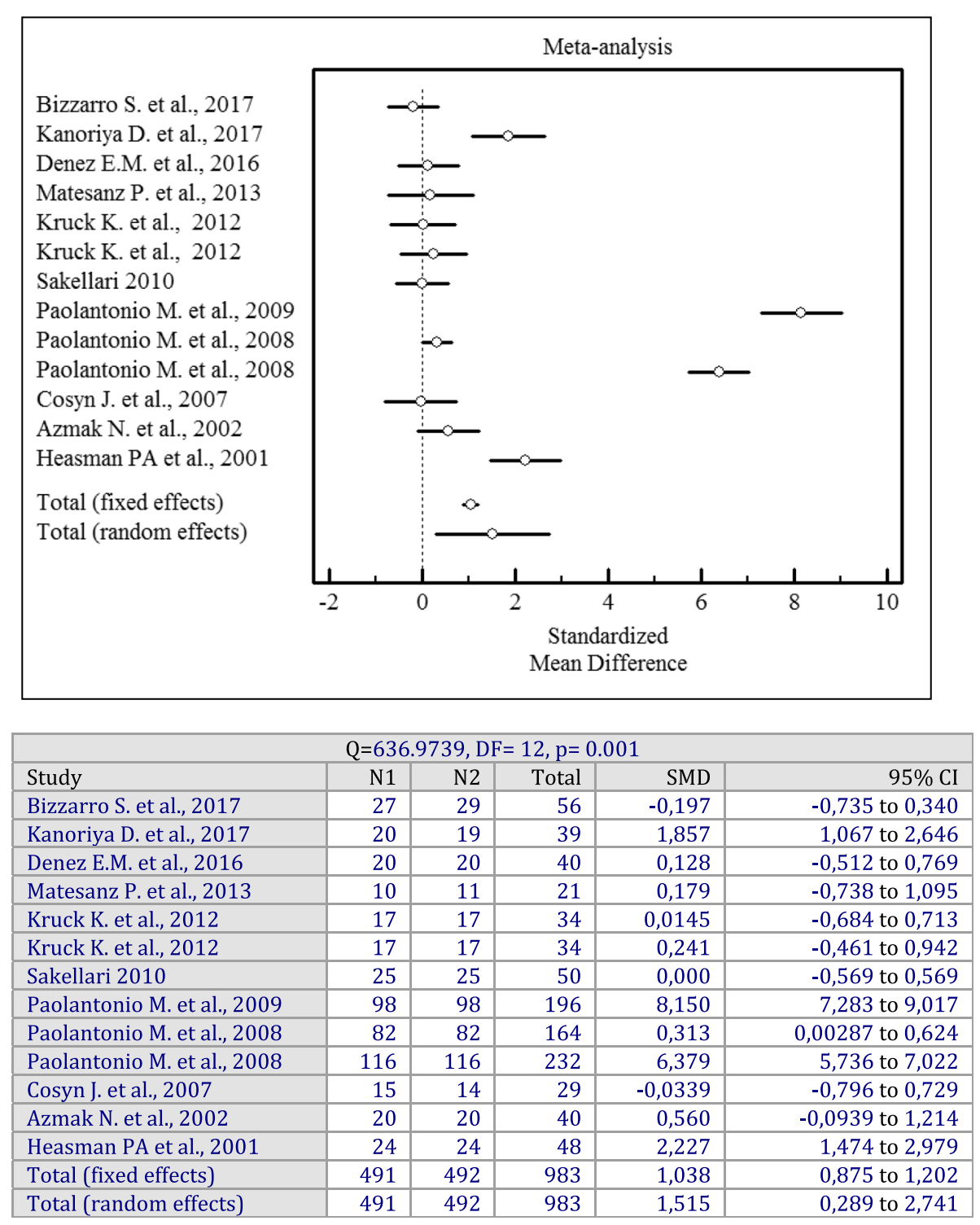

Fig. 3 Forest plot of odds ratio $(95 \%$ Cl) for clinical attachment level using adjunctive antiseptics 


\section{Inclusion and exclusion criteria}

During the first stage of study selection, the titles and abstracts were screened and evaluated according to the following inclusion criteria:

- Randomized controlled clinical trials (RCTs) comparing the effectiveness of one or more antiseptic agents as adjuncts to SRP;

- An antiseptic was applied to periodontal pockets only at the time of SRP;

- A control group received the same SRP as the test group either alone or with a placebo;

- SRP was carried out with both ultrasonic and hand instruments;

- A follow-up no less than 6 months;

- Parallel and split-mouth design studies including systemically healthy chronic periodontitis patients;

- The study reported on clinical treatment outcomes, including PD and/or CAL and/or BOP;
- If multiple antimicrobials were tested, outcomes were reported separately for each agent;

- English language.

At the second stage of selection, all full-text articles identified during the first stage were acquired and evaluated according to the following exclusion criteria:

- Studies including patients with systemic diseases;

- Studies where aggressive periodontitis patients were treated;

- Studies where antiseptics were continuously reapplied to progressing tooth sites or applied before the initial periodontal treatment;

- Studies where SRP was performed only with ultrasonic instruments;

- Studies not reporting on the clinical treatment outcomes, including changes in CAL and/or PD and/or BOP.

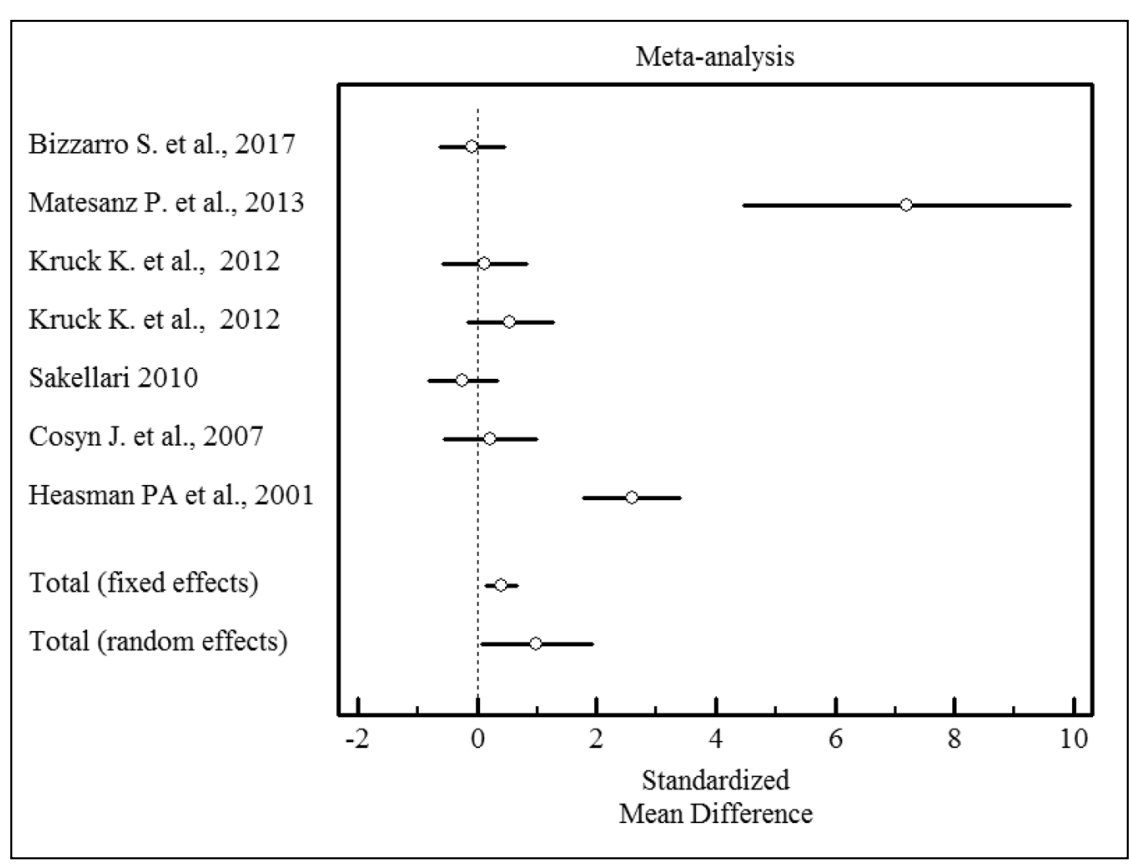

\begin{tabular}{|l|r|r|r|r|r|}
\hline \multicolumn{2}{|c|}{$\mathrm{Q}=636.9739, \mathrm{DF}=12, \mathrm{p}=0.001$} \\
\hline Study & $\mathrm{N} 1$ & $\mathrm{~N} 2$ & Total & Odds ratio & 95\% CI \\
\hline Bizzarro S. et al., 2017 & 27 & 29 & 56 & $-0,0855$ & $-0,622$ to 0,451 \\
\hline Matesanz P. et al., 2013 & 10 & 11 & 21 & 7,200 & 4,463 to 9,937 \\
\hline Kruck K. et al., 2012 & 17 & 17 & 34 & 0,122 & $-0,578$ to 0,821 \\
\hline Kruck K. et al., 2012 & 17 & 17 & 34 & 0,548 & $-0,165$ to 1,261 \\
\hline Sakellari 2010 & 25 & 25 & 50 & $-0,242$ & $-0,813$ to 0,329 \\
\hline Cosyn J. et al., 2007 & 15 & 14 & 29 & 0,219 & $-0,546$ to 0,984 \\
\hline Heasman PA et al., 2001 & 24 & 24 & 48 & 2,595 & 1,790 to 3,399 \\
\hline Total (fixed effects) & 135 & 137 & 272 & 0,409 & 0,148 to 0,670 \\
\hline Total (random effects) & 135 & 137 & 272 & 0,995 & 0,0761 to 1,913 \\
\hline
\end{tabular}

Fig. 4 Forest plot of odds ratio $(95 \% \mathrm{Cl})$ for bleeding on probing using adjunctive antiseptics 


\section{Data extraction}

Data extraction templates were used to retrieve general information on the country, study design, periodontal status of included cohorts, follow-up periods, number of patients, patients' gender, age, smoking status, and tested products (Table 1). The number of patients at baseline and at end of the study, periodontal case definitions, treatment protocols, and clinical outcomes are presented in Table 2. The mean values and standard deviations of changes in PD and BOP reduction and in CAL gain following the treatment in test and control groups were extracted for the data analysis (Table 2). In cases where a study did not report exact data of interest but included precise graphic representations, data were extracted.

When the differences $(\Delta)$ between baseline-end visits were not reported, they were calculated according to the formula: $\Delta$ Vary = Var2-Var1 (Var1 and Var2 - mean values before and after treatment). The variance was estimated with the formula: $\mathrm{SVar}^{2}=\mathrm{SVar}^{2}-\mathrm{SVar}^{2}$ $\left(2 *{ }^{*}{ }^{*}\right.$ SVar1*SVar2), (SVar1 ${ }^{2}$ and SVar2 ${ }^{2}$ - variances of the mean baseline and end values) [29]. A correlation $r$ of 0,5 was assumed [30].

\section{Risk of bias assessment}

The quality of all included studies was assessed during the data extraction process and involved an evaluation of the methodological elements that could influence each study's outcome (Table 3). The Cochrane Collaboration's 2-part tool for assessing the risk of bias [31] was used to assess bias across the studies and to identify papers with intrinsic methodological and design flaws. The following items were evaluated as posing a low, high, or unclear risk of bias: 1) random sequence generation, 2) allocations concealment, 3) the blinding of participants/ personnel, 4) incomplete outcome data, 5) selective reporting outcomes, 6) other potential risks of bias. The

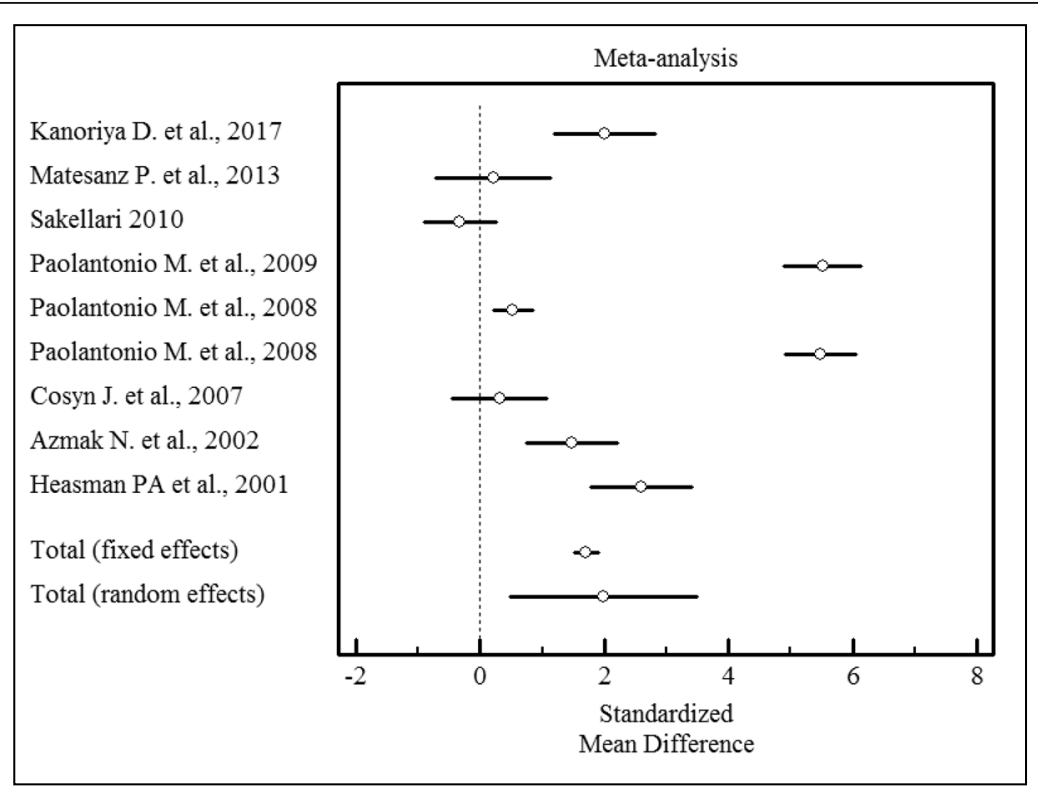

\begin{tabular}{|l|r|r|r|r|r|}
\hline \multicolumn{7}{|c|}{$\mathrm{Q}=454.9179, \mathrm{DF}=8, \mathrm{p}=0.001$} \\
\hline Study & $\mathrm{N} 1$ & $\mathrm{~N} 2$ & Total & SMD & $95 \%$ CI \\
\hline Kanoriya D. et al., 2017 & 20 & 19 & 39 & 2,003 & 1,193 to 2,813 \\
\hline Matesanz P. et al., 2013 & 10 & 11 & 21 & 0,207 & $-0,711$ to 1,124 \\
\hline Sakellari 2010 & 25 & 25 & 50 & $-0,323$ & $-0,896$ to 0,249 \\
\hline Paolantonio M. et al., 2009 & 98 & 98 & 196 & 5,512 & 4,890 to 6,134 \\
\hline Paolantonio M. et al., 2008 & 82 & 82 & 164 & 0,523 & 0,209 to 0,836 \\
\hline Paolantonio M. et al., 2008 & 116 & 116 & 232 & 5,482 & 4,914 to 6,050 \\
\hline Cosyn J. et al., 2007 & 15 & 14 & 29 & 0,308 & $-0,460$ to 1,075 \\
\hline Azmak N. et al., 2002 & 20 & 20 & 40 & 1,470 & 0,740 to 2,200 \\
\hline Heasman PA et al., 2001 & 24 & 24 & 48 & 2,595 & 1,790 to 3,399 \\
\hline Total (fixed effects) & 410 & 409 & 819 & 1,702 & 1,512 to 1,892 \\
\hline Total (random effects) & 410 & 409 & 819 & 1,977 & 0,470 to 3,485 \\
\hline
\end{tabular}

Fig. 5 Forest plot of odds ratio $(95 \% \mathrm{Cl})$ probing depth reduction using adjunctive sustained-release vehicle antiseptics 
degree of bias was categorized as low risk if all criteria were met, moderate risk when one criterion was missing, and high risk if two or more criteria were missing.

\section{Statistical analysis}

All meta-analyses were performed on randomized controlled clinical trials that reported the clinical outcomes of nonsurgical periodontitis treatment utilizing various adjunctive antiseptics.

Individual trials were pooled, and the overall rates of probing-depth reduction, clinical attachment level gains, bleeding-on-probing reduction, and the 95\% confidence intervals (CIs) among the treatment groups were calculated. Fixed or random effects models were used based on the presence or absence of heterogeneity among the included studies. The heterogeneity among the included trials was tested by the heterogeneity test using the Cochran Q statistics. In our case the random-effects model (the Der Simonian and Liard method) [32] was more eligible, as it tended to give a more more conservative estimate, nevertheless the results of both models usually agreed well. An unweighted kappa index was used to evaluate the level of agreement between 2 independent researchers.

\section{Results}

\section{Study selection}

The initial search resulted in 9420 articles from the MEDLINE (Ovid) and Cohrane Central Register of Controlled Trials (CENTRAL) databases. After evaluating titles and abstracts, inclusion and exclusion criteria were applied to the remaining 27 full-text articles (inter-reader agreement $\mathrm{K}=0.85$ ). Finally, 12 RCTs were included into the review (inter-reader agreement $\mathrm{K}=0.96$ ). The study selection process is presented in Fig. 1.

\section{Study exclusion}

The reasons for excluding studies after full-text assessment were as follows: a follow-up time $<6$ months $(n=$ 7) [33-39], antiseptics applied to periodontal pockets prior to periodontal treatment $(n=1)$ [40], antiseptics applied continuously to worsening sites after an initial periodontal treatment $(n=3)$ [41-43], repeated periodontal treatment and antiseptics applied at all followup visits $(n=1)$ [44], and periodontal treatment established only by ultrasonic instruments $(n=3)$ [45-47].

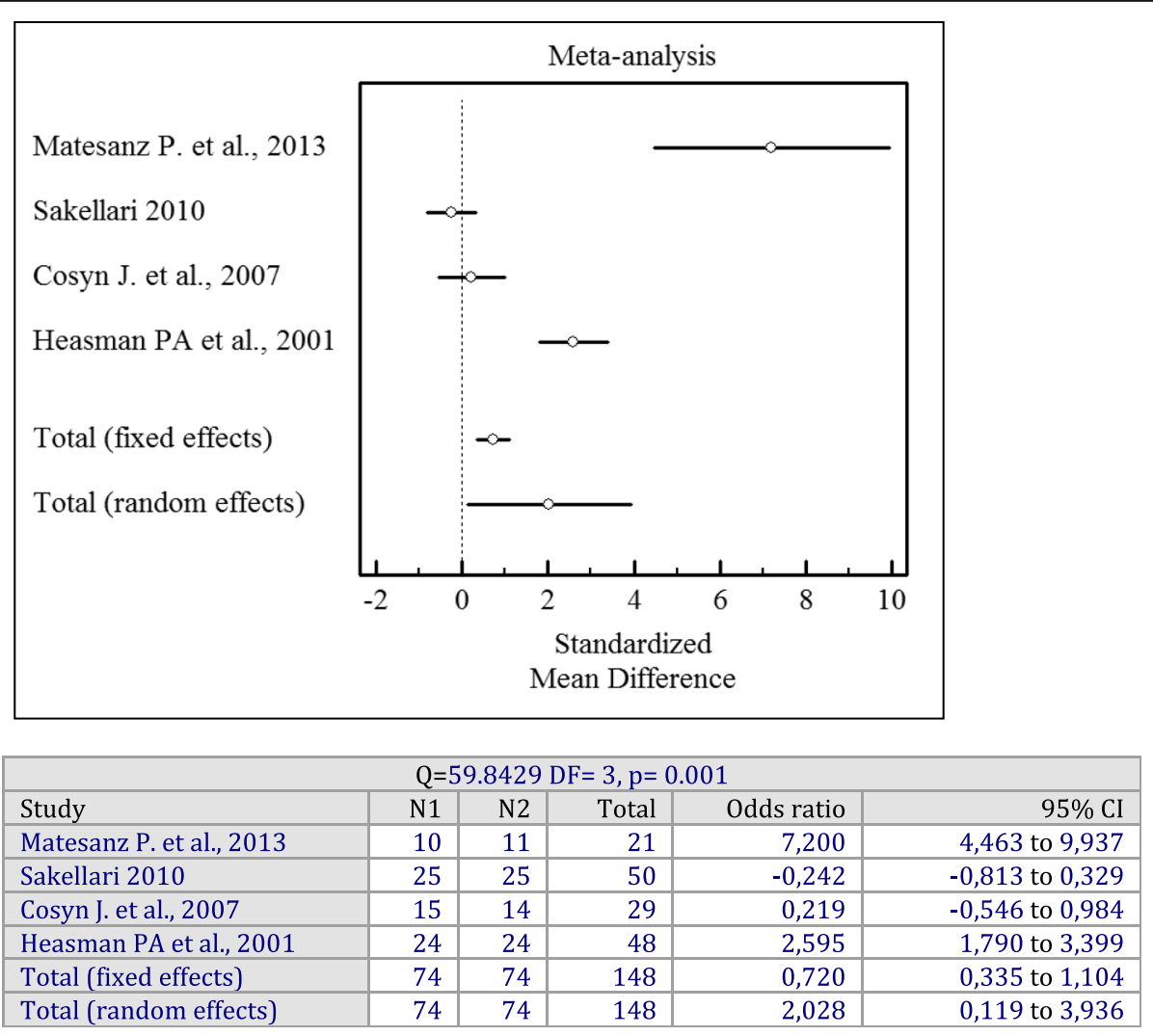

Fig. 6 Forest plot of odds ratio $(95 \% \mathrm{Cl})$ for bleeding on probing reduction using adjunctive sustained-release vehicle antiseptics 


\section{Quality assessment}

To summarize the risk of bias for each study, 3 studies were classified as having a low risk of bias (all domains included) $[13,15,20], 5$ studies had a moderate risk (bias for 1 key domain [14, 22-25], and 4 studies were judged to have a high risk of bias (more than 1 domain) $[14,21,26,27]$.

\section{Study design}

The included studies are described in Table 1. Six studies used a split-mouth design [14, 22-24, 26, 27], whereas the remaining investigations had a parallel arms design [13-15, 20, 21, 25]. The follow-up period ranged from 6 (10 studies [14, 15, 20, 22-27]) to 12 months (2 studies $[13,21])$. Two of the studies had more than one test group (i.e., two [21] and three [13] test groups). However, due to the adjunctive use of systemic antibiotics following the SRP, only one test group of one of the aforementioned studies [13] was included in the current analysis.

\section{Study population}

The present analysis involved a total of 632 consecutive periodontal patients $[13-15,21-26]$ and patients enrolled in a regular periodontal maintenance program $[20,27]$. In total, $606(95.8 \%)$ patients completed the studies. The mean age of the included patients ranged from 22 [14] to 75 years [15], and the ratio of included males and females varied from 0.30 [23] to 0.67 [27]. Ten studies [13-15, 20-25, 27] were based on patient samples from a European population, and 2 studies [14, 26] were based on an Asian population.

Two studies [21, 25] did not report on patient smoking habits, and smokers were excluded in 7 studies [14, $22-24,26,27]$. In 3 investigations $[13,15,20]$ that

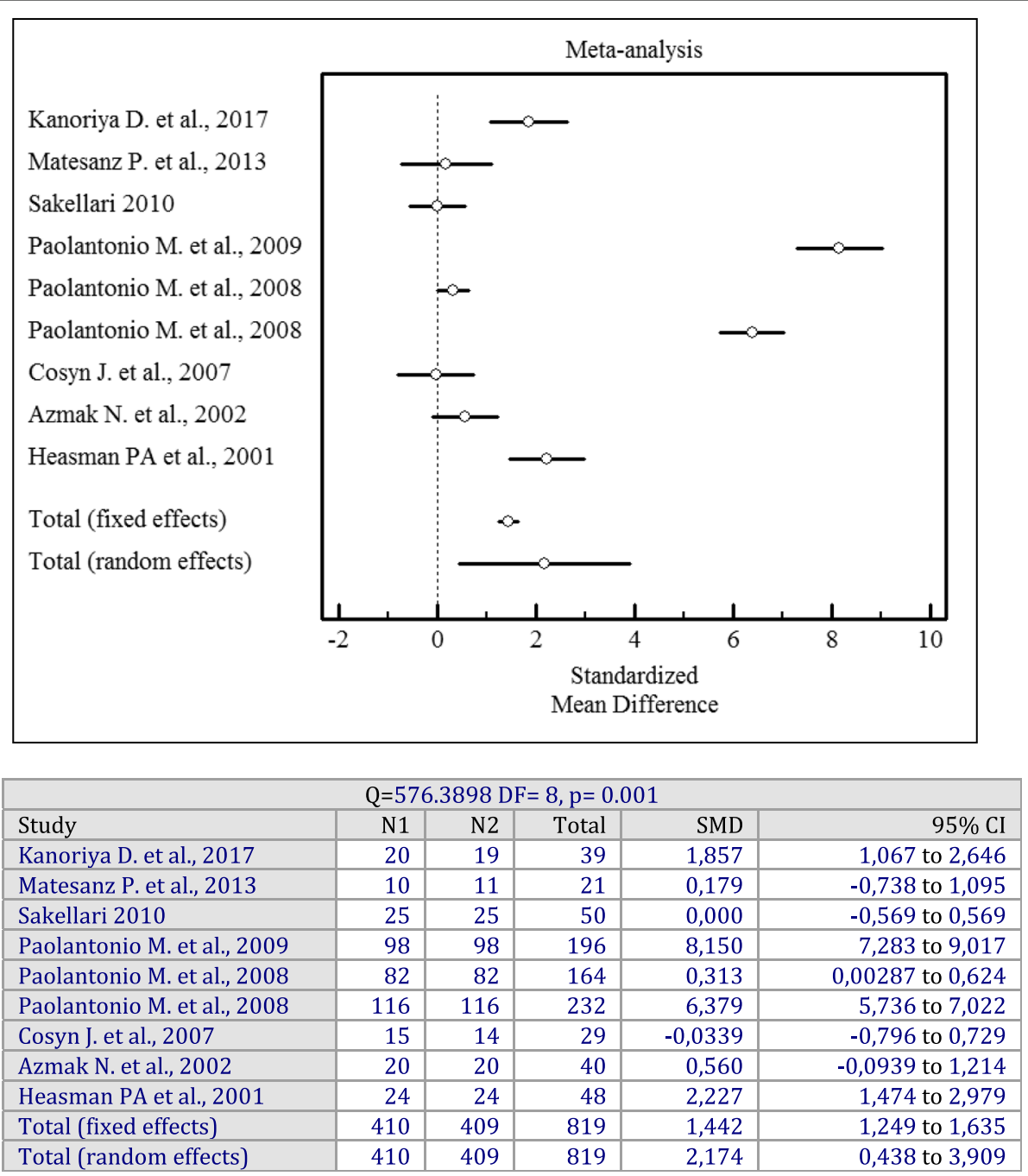

Fig. 7 Forest plot of odds ratio $(95 \%$ Cl) for clinical attachment gain using adjunctive sustained-release vehicle antiseptics 
included smoking patients, the proportion of smokers ranged from $16 \%$ [15] to $55 \%$ [13].

Patient-related data are depicted in Table 1.

\section{Antiseptics}

Table 1 shows antiseptic materials adjunctively applied during the SRP. Studies were divided into 2 broad groups based on the vehicle employed to deliver the antiseptic agent: adjunctive sustained-release antiseptics (gels, chips, and varnish $[14,15,20,22-27])$ and adjunctive irrigation with antiseptics (antiseptic delivered by syringe $[13,14,21])$.

\section{Interventions}

Treatment protocols used in the test and control groups are depicted in Table 2. Full-mouth SRP was accomplished in all studies before the application of tested materials. Two studies $[14,20]$ used placebos in the control groups. In all studies, oral hygiene instructions were given to the patients prior to treatment, and oral hygiene was reinforced at each follow-up visit. Except for 1 study [13] where patients were prescribed to rinse with $0.12 \%$ chlorhexidine, additional postoperative antiseptic rinsing was restricted in the remaining studies.

\section{Synthesis of results}

Meta-analyses were performed only if studies with similar comparisons reported the same outcome measures.

In spite of a high heterogeneity among the included studies $\left(\mathrm{I}^{2}=97 \%, p=0.001\right)$, an evaluation of the overall effect of antiseptics used as adjuncts to SRP showed statistically significant changes for the PD $(p=0.001$; $\mathrm{SMD}=1.536,95 \% \mathrm{CI}=0.402$ to 2.670$)$, $\mathrm{CAL}(p=0.001$; $\mathrm{SMD}=1.515,95 \% \mathrm{CI}=0.289$ to 2.741$)$, and $\mathrm{BOP}(p=$ 0.001 ; $\mathrm{OR}=0.995,95 \% \mathrm{CI}=0.0761$ to 1.913 ) values irrespective of the antiseptics delivery vehicle compared to SRP alone.

Forest plots of odds ratios (95\% CI) for PD, CAL, and BOP using adjunctive antiseptics with SRP are demonstrated in Figs. 2, 3 and 4.

\section{Adjunctive sustained-release antiseptics}

Nine studies [14, 15, 20, 22-27] with 405 patients were included in a meta-analysis for PD and CAL changes.

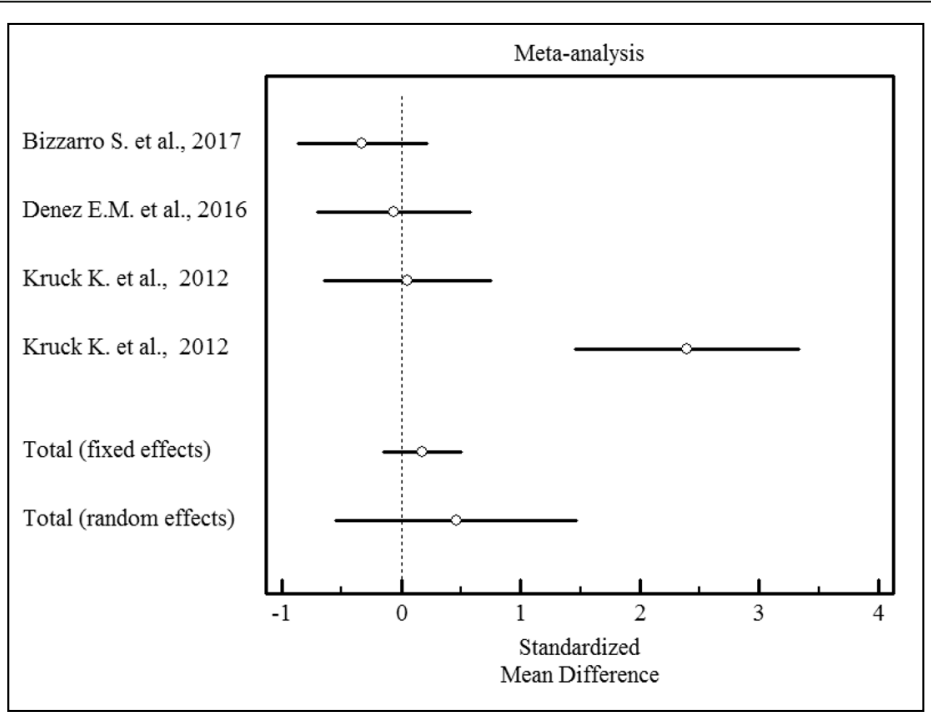

\begin{tabular}{|l|r|r|r|r|r|}
\hline \multicolumn{7}{|c|}{$\mathrm{Q}=27.3343 \mathrm{DF}=3, \mathrm{p}=0.321$} \\
\hline Study & $\mathrm{N} 1$ & $\mathrm{~N} 2$ & Total & SMD & $95 \%$ CI \\
\hline Bizzarro S. et al., 2017 & 27 & 29 & 56 & $-0,329$ & $-0,869$ to 0,211 \\
\hline Denez E.M. et al., 2016 & 20 & 20 & 40 & $-0,0653$ & $-0,706$ to 0,575 \\
\hline Kruck K. et al., 2012 & 17 & 17 & 34 & 0,0488 & $-0,650$ to 0,748 \\
\hline Kruck K. et al., 2012 & 17 & 17 & 34 & 2,394 & 1,454 to 3,335 \\
\hline Total (fixed effects) & 81 & 83 & 164 & 0,175 & $-0,150$ to 0,500 \\
\hline Total (random effects) & 81 & 83 & 164 & 0,460 & $-0,546$ to 1,467 \\
\hline
\end{tabular}

Fig. 8 Forest plot of odds ratio $(95 \% \mathrm{Cl})$ for probing depth reduction using adjunctive irrigant antiseptics 
The meta-analysis found that a sustained-release delivery of antiseptics resulted in a significantly greater PD reduction compared to SRP alone $(p=0.001)$. There was significant heterogeneity among studies $\left(\mathrm{I}^{2}=98 \%, \mathrm{Q}=\right.$ 454.9179, $\mathrm{df}=8, p=0.001, \mathrm{SMD}=1.977 \mathrm{~mm} ; 95 \% \mathrm{CI}$ : 0.470 to 3.485$)$.

Likewise, when considering the CAL changes, a sustained-release delivery system of antiseptics demonstrated statistically significant greater gains in CAL compared to SRP alone $(p=0.001)$. There was significant heterogeneity among studies $\left(\mathrm{I}^{2}=98 \%, \mathrm{Q}=576.4\right.$, $\mathrm{df}=8, p=0.001, \mathrm{SMD}=2.174 \mathrm{~mm} ; 95 \% \mathrm{CI}: 0.438$ to 3.909).

Four studies with 124 patients were included in a meta-analysis for the changes of BOP [15, 20, 25, 27]. Its findings pointed to a statistically significant higher reduction in BOP scores when sustained-release antiseptics were applied compared to SRP alone $(p=0.001)$. Significant heterogeneity among the studies was found $\left(\mathrm{I}^{2}=94 \%, \mathrm{Q}=59.8429, \mathrm{df}=3, p=0.001, \mathrm{OR}=2.028 ; 95 \%\right.$ CI: 0.119 to 3.936$)$.

Forest plots of odds ratios $(95 \% \mathrm{CI})$ for PD, BOP reduction, and CAL gains using adjunctive antiseptics for scaling and root planning in a sustained-release vehicle are demonstrated in Figs. 5, 6 and 7.

\section{Adjunctive irrigation with antiseptics}

For the meta-analysis evaluating the effectiveness of adjunctive subgingival irrigation with antiseptics in terms of PD and CAL changes, 3 studies with 127 patients were included $[13,14,21]$. The results demonstrated that a liquid form of subgingivally applied antiseptics did not significantly change PD values compared to SRP alone $(p=0.321)$. There was significant heterogeneity among studies $\left(\mathrm{I}^{2}=89 \%, \mathrm{Q}=27.3343 \mathrm{df}=3, p=0.321\right.$, $\mathrm{SMD}=0.460 \mathrm{~mm} ; 95 \% \mathrm{CI}:-0.546$ to 1.467$)$.

Similarly, liquid forms of antiseptics did not significantly change CAL compared to SRP alone $(p=0.7568)$. There was no significant heterogeneity among studies $\left(\mathrm{I}^{2}=0 \%, \mathrm{Q}=1.1843, \mathrm{df}=3, p=0.7568, \mathrm{SMD}=0.0169\right.$; 95\% CI: -0.292 to 0.326 ).

Based on the two studies with 107 patients, the additional application of a liquid form of antiseptics did not significantly reduce BOP as compared to SRP alone ( $p=$ $0.3549)[13,21]$. These studies did not demonstrate significant heterogeneity $\left(\mathrm{I}^{2}=7 \%, \mathrm{Q}=2.07, \mathrm{df}=2, p=\right.$ $0.3549, \mathrm{OR}=0.141 ; 95 \% \mathrm{CI}:-0.217$ to 0.499$)$.

Forest plots of odds ratios $(95 \% \mathrm{CI})$ for PD, BOP reduction, and CAL gains using adjunctive antiseptics for scaling and root planning in additional irrigation studies are demonstrated in Figs. 8, 9 and 10.

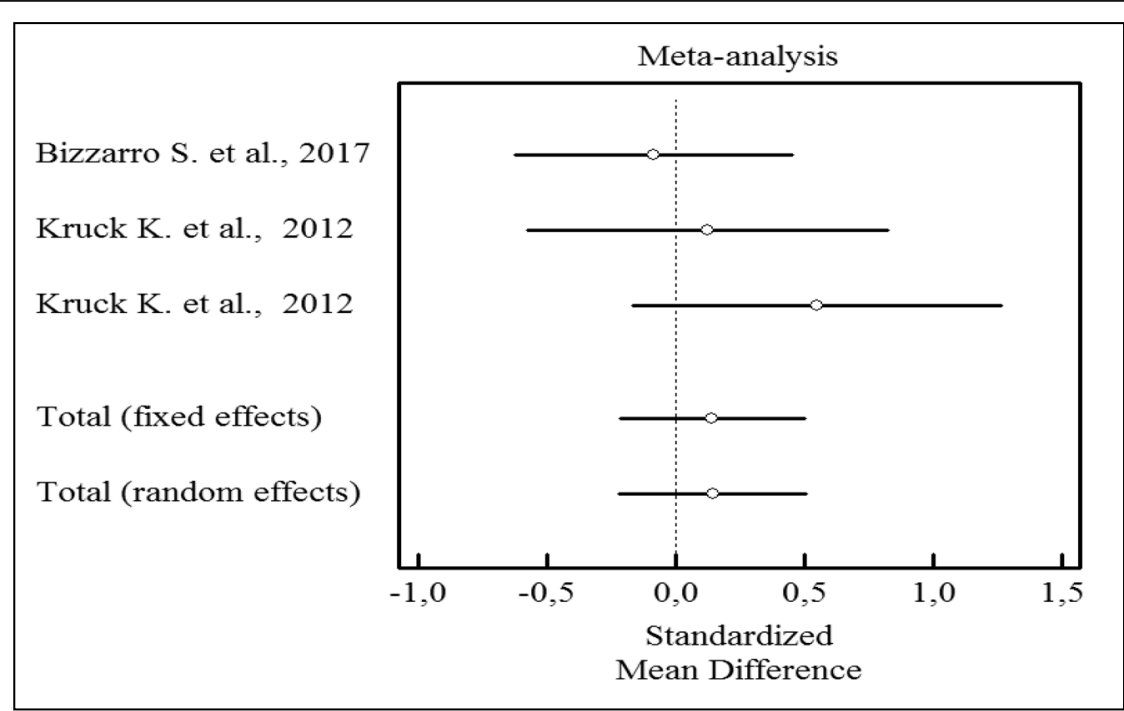

\begin{tabular}{|l|r|r|r|r|r|}
\hline \multicolumn{7}{|c|}{$\mathrm{Q}=2.0716 \mathrm{DF}=2, \mathrm{p}=0.3549$} \\
\hline Study & $\mathrm{N} 1$ & $\mathrm{~N} 2$ & Total & Odds ratio & $95 \% \mathrm{CI}$ \\
\hline Bizzarro S. et al., 2017 & 27 & 29 & 56 & $-0,0855$ & $-0,622$ to 0,451 \\
\hline Kruck K. et al., 2012 & 17 & 17 & 34 & 0,122 & $-0,578$ to 0,821 \\
\hline Kruck K. et al., 2012 & 17 & 17 & 34 & 0,548 & $-0,165$ to 1,261 \\
\hline Total (fixed effects) & 61 & 63 & 124 & 0,141 & $-0,217$ to 0,499 \\
\hline Total (random effects) & 61 & 63 & 124 & 0,143 & $-0,222$ to 0,508 \\
\hline
\end{tabular}

Fig. 9 Forest plot of odds ratio $(95 \% \mathrm{Cl})$ for bleeding on probing using adjunctive irrigant antiseptics 


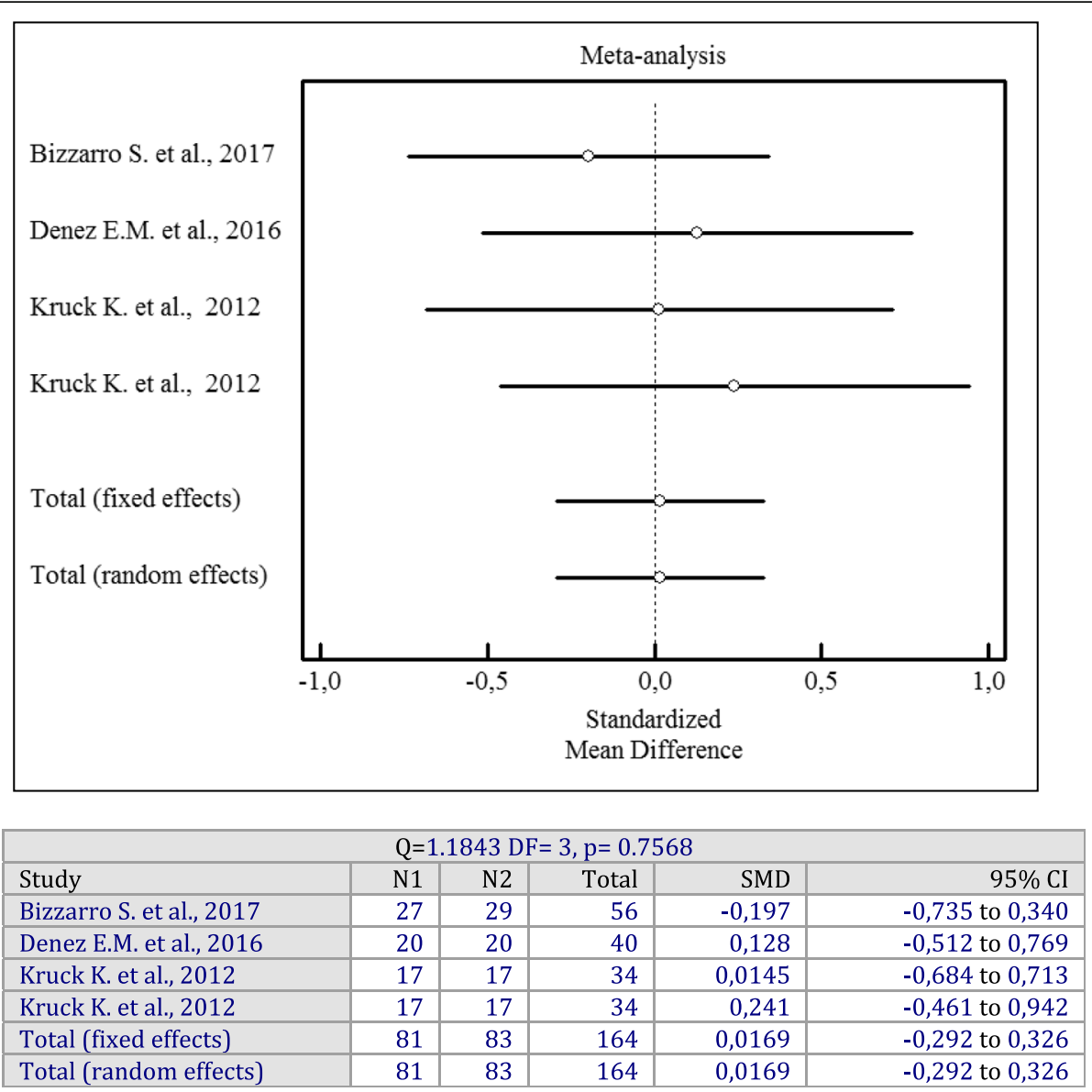

Fig. 10 Forest plot of odds ratio $(95 \%$ Cl) for clinical attachment level gain using adjunctive irrigant antiseptics

\section{Discussion}

The present study aimed to investigate the potential beneficial effects of the adjunctive application of subgingivally delivered antiseptics to SRP for treating periodontitis patients.

Based on our findings, the overall use of adjuvant antiseptics brings an additional clinical advantage compared to SRP alone. The meta-analysis demonstrated significant improvements in PD, CAL values, and BOP scores following the subgingival application of antiseptics compared to the control (SRP alone) $(p=0.001)$. However, these improvements were shown to depend on the antiseptics' delivery vehicle. Particularly, only antiseptics with a sustained-release vehicle (gels, chips, and varnish) were found to have significant clinical improvements in terms of PD, BOP reduction, and CAL gain $(p=0.001)$. The addition of subgingival irrigation with antiseptics failed to show significant improvement of clinical parameters compared to the controls $(p>0.05)$.

The effectiveness of using adjunctive local antiseptics in combination with SRP was evaluated in previous systematic reviews [29, 48-50]. Accordingly to our findings, different $\mathrm{CHX}$ concentrations using various administration vehicles (CHX chips, $\mathrm{CHX}$ varnish, and $\mathrm{CHX}$ plus xanthan gel) showed an overall significant effect with significant differences $(p=0.000)$ for changes in PD and in CAL compared to SRP alone $[29,48]$. Moreover, a positive adjunctive effect (i.e., significant PD reduction $(p=0.058)$ and CAL gains $(p=0.015))$ of sustained-release antiseptics (CHX chips), but not irrigated (CHX solution), in combination with SRP was demonstrated [50].

The aforementioned systematic reviews also evaluated adjunctive benefits of locally delivered antibiotics with a sustained-release delivery $[29,48-50]$. Their clinical efficacy in terms of PD and BOP reduction and CAL gain was comparable to the efficacy obtained with sustained-release antiseptics. However, it was previously highlighted that the use of locally delivered antibiotics should be limited [16]. Therefore, we did not intend to investigate the clinical benefits of adjuvant local antibiotics with SRP in the current review.

Two of the included studies found the initial PD values to be associated with the treatment outcomes [14, 25]. In particular, initial probing depths of $6 \mathrm{~mm}$ and 7 
$\mathrm{mm}$ were shown to result in significantly greater PD reductions when compared with the baseline PD values of $<5 \mathrm{~mm}[14,25]$. As stated in a study by Salvi et al. [51], a PD reduction of $2 \mathrm{~mm}$ to $2.5 \mathrm{~mm}$ in sites exceeding 6 $\mathrm{mm}$ at baseline is to be expected. Therefore, additional pocket reduction would represent a true clinical benefit of adjunctive therapies [51]. Aforementioned studies [14, 25] found extra PD reduction in initially deep sites in favor of test groups ( 0.93 and $2 \mathrm{~mm}$ respectively), thus indicating a clinical advantage of adjunctive antiseptics in deep periodontal pockets.

A current investigation of various antiseptic materials analyzed their various formulations and delivery forms, which did not allow us to subgroup the studies according to antiseptic agents. This suggests the need for well-designed, longterm randomized controlled clinical trials utilizing antiseptics as adjuncts to SRP in the treatment of periodontitis.

This systematic review was limited to only randomized controlled clinical studies. The current review only included studies written in English, which could introduce a publication bias.

Only $3[13,15,20]$ out of 12 studies had a low risk of bias, which included relatively small number of patients. Other studies were evaluated as having a moderate $(n=5)$ or high $(n=4)$ risk of bias. These aspects are important for detecting methodological weaknesses of the included studies that might alter therapy outcomes. According to the results of a bias risk assessment, allocation concealment and the blinding of participants and personnel appeared to be the most critical domains.

In the current review, data for investigated primary and secondary outcome variables showed a high degree of heterogeneity ( $>85 \%)$. Factors that impact it might include differences of the studied populations, differences in disease severity, the therapeutic agent's type and concentration, and the location of defects, which makes it difficult to evaluate the real effect of tested products.

Only studies with a follow-up of no less than 6 months were included in the review; thus, results from studies with a shorter follow-up period were not included in the analysis, which might influence our results. For example, Matesanz et al. [20] found statistically significant PD reductions in short-term studies (studies with a follow-up of less than 6 months) for additional CHX chips $(n=7)$ and $\mathrm{CHX}$ varnish $(n=2)$ and significant CAL gains for CHX chips $(n=8)$.

Analyzed studies included relatively small number of patients, thus questioning if the real effect of tested materials could be detected. In particular, 3 studies [22-24] with big study cohorts found significant clinical improvements for the adjunctive use of subgingival antiseptics, suggesting the need for large trials encompassing bigger study cohorts.

\section{Conclusions}

Based on the findings of the current systematic review, adjunctive subgingivally delivered antiseptics with a sustained-release delivery have significant clinical benefits compared to SRP alone. Furthermore, future studies should be based on adequate methodological procedures to improve the overall quality of the reporting and to reduce the risk of bias.

\section{Abbreviations}

BOP: Bleeding on probing; CAL: Clinical attachment level; CHX: Chlorhexidine digluconate; Cl: Confidence intervals; DF: Degrees of freedom; PD: Probing

depth; SMD: Standard mean deviation; SRP: Scaling and root planing

\section{Acknowledgements}

The authors would like to acknowledge Irena Nedzelskiene for the help with statistical analysis.

\section{Authors' contributions}

ER: selected the papers, performed papers validity assessment, prepared the manuscript; VM: selected the papers, performed papers validity assessment; Both authors read and approved the final version of the manuscript.

\section{Authors' information}

Egle Ramanauskaite DDS: PhD student, Clinic of Dental and Oral Pathology, Lithuanian University of Health Sciences, Kaunas, Lithuania.

Vita Machiulskiene DDS, MSD, PhD: Professor, Clinic of Dental and Oral

Pathology, Lithuanian University of Health Sciences, Kaunas, Lithuania.

\section{Funding}

None.

Availability of data and materials

All data generated or analysed during this study are included in this published Article.

Ethics approval and consent to participate

Not applicable as this paper is a systematic review.

Consent for publication

Not applicable.

\section{Competing interests}

The authors declare that they have no competing interests. There are no financial completing interests as we have not received any grants. The authors alone are responsible for the content and writing of the paper.

Received: 29 September 2019 Accepted: 29 April 2020

Published online: 18 May 2020

\section{References}

1. Papapanou PN, Sanz M, Buduneli N, Dietrich T, Feres M, Fine DH, Flemmig TF, Garcia R, Giannobile WV, Graziani F, Greenwell H, Herrera D, Kao RT, Kebschull M, Kinane DF, Kirkwood KL, Kocher T, Kornman KS, Kumar PS, Loos BG, Machtei E, Meng H, Mombelli A, Needleman I, Offenbacher S, Seymour GJ, Teles R, Tonetti MS. Periodontitis: Consensus report of workgroup 2 of the 2017 world workshop on the classification of periodontal and peri-implant diseases and conditions. J Clin Periodontol. 2018;45(Suppl 20):S162-70.

2. Jepsen S, Blanco J, Buchalla W, Carvalho JC, Dietrich T, Dorfer C, Eaton KA, Figuero E, Frencken JE, Graziani F, Higham SM, Kocher T, Maltz M, OrtizVigon A, Schmoeckel J, Sculean A, Tenuta LM, van der Veen MH, Machiulskiene V. Prevention and control of dental caries and periodontal diseases at individual and population level: consensus report of group 3 of joint EFP/ORCA workshop on the boundaries between caries and periodontal diseases. J Clin Periodontol. 2017;44(Suppl 18):S85-93.

3. Armitage GC. Development of a classification system for periodontal diseases and conditions. Ann Periodontol. 1999;4:1-6. 
4. Tonetti MS, Greenwell H, Kornman KS. Staging and grading of periodontitis: framework and proposal of a new classification and case definition. J Periodontol. 2018;89(Suppl 1):S159-72.

5. Graziani F, Karapetsa D, Alonso B, Herrera D. Nonsurgical and surgical treatment of periodontitis: How many options for one disease? Periodontol. 2000;2017(75):152-88.

6. Teles RP, Haffajee AD, Socransky SS. Microbiological goals of periodontal therapy. Periodontol. 2000;2006(42):180-218.

7. Petersilka GJ, Ehmke B, Flemmig TF. Antimicrobial effects of mechanical debridement. Periodontol. 2000;2002(28):56-71.

8. Eick S, Nydegger J, Burgin W, Salvi GE, Sculean A, Ramseier C. Microbiological analysis and the outcomes of periodontal treatment with or without adjunctive systemic antibiotics-a retrospective study. Clin Oral Investig. 2018.

9. Cosgarea R, Heumann C, Juncar R, Tristiu R, Lascu L, Salvi GE, Arweiler NB, Sculean A. One year results of a randomized controlled clinical study evaluating the effects of non-surgical periodontal therapy of chronic periodontitis in conjunction with three or seven days systemic administration of amoxicillin/metronidazole. PLoS One. 2017;12:e0179592.

10. Bland PS, Goodson JM, Gunsolley JC, Grossi SG, Otomo-Corgel J, Doherty F, Comiskey JL. Association of antimicrobial and clinical efficacy: periodontitis therapy with minocycline microspheres. J Int Acad Periodontol. 2010;12:11-9.

11. Machion L, Andia DC, Lecio G, Nociti FH Jr, Casati MZ, Sallum AW, Sallum EA. Locally delivered doxycycline as an adjunctive therapy to scaling and root planing in the treatment of smokers: a 2-year follow-up. J Periodontol. 2006;77:606-13.

12. Pradeep AR, Sagar SV, Daisy H. Clinical and microbiologic effects of subgingivally delivered $0.5 \%$ azithromycin in the treatment of chronic periodontitis. J Periodontol. 2008;79:2125-35.

13. Bizzarro S, Van der Velden U, Loos BG. Local disinfection with sodium hypochlorite as adjunct to basic periodontal therapy: a randomized controlled trial. J Clin Periodontol. 2016:43:778-88.

14. Kanoriya D, Singhal S, Garg V, Pradeep AR, Garg S, Kumar A. Clinical efficacy of subgingivally-delivered $0.75 \%$ boric acid gel as an adjunct to mechanotherapy in chronic periodontitis: A randomized, controlled clinical trial. J Investig Clin Dent. 2018;9. https://doi.org/10.1111/jicd.12271 Epub 2017 May 5.

15. Sakellari D, loannidis I, Antoniadou M, Slini T, Konstantinidis A. Clinical and microbiological effects of adjunctive, locally delivered chlorhexidine on patients with chronic periodontitis. J Int Acad Periodontol. 2010;12:20-6.

16. Jepsen K, Jepsen S. Antibiotics/antimicrobials: Systemic and local administration in the therapy of mild to moderately advanced periodontitis. Periodontol. 2000;2016(71):82-112.

17. Sanz M, Teughels W, Group A of European Workshop on Periodontology. Innovations in non-surgical periodontal therapy: consensus report of the sixth european workshop on periodontology. J Clin Periodontol 2008;35:3-7.

18. Slots J. Selection of antimicrobial agents in periodontal therapy. Periodontal Res. 2002;37:389-98.

19. Moher D, Liberati A, Tetzlaff J, Altman DG, PRISMA Group. Preferred reporting items for systematic reviews and meta-analyses: the PRISMA statement. Int J Surg 2010;8:336-341.

20. Matesanz P, Herrera D, Echeverria A, O'Connor A, Gonzalez I, Sanz M. A randomized clinical trial on the clinical and microbiological efficacy of a xanthan gel with chlorhexidine for subgingival use. Clin Oral Investig. 2013; 17:55-66.

21. Heasman PA, Heasman L, Stacey F, McCracken Gl. Local delivery of chlorhexidine gluconate (PerioChip) in periodontal maintenance patients. J Clin Periodontol. 2001;28:90-5.

22. Paolantonio M, D'Ercole S, Pilloni A, D'Archivio D, Lisanti L, Graziani F, Femminella B, Sammartino G, Perillo L, Tete S, Perfetti G, Spoto G, Piccolomini R, Perinetti G. Clinical, microbiologic, and biochemical effects of subgingival administration of a xanthan-based chlorhexidine gel in the treatment of periodontitis: a randomized multicenter trial. J Periodontol. 2009:80:1479-92

23. Paolantonio M, D'Angelo M, Grassi RF, Perinetti G, Piccolomini R, Pizzo G, Annunziata M, D'Archivio D, D'Ercole S, Nardi G, Guida L. Clinical and microbiologic effects of subgingival controlled-release delivery of chlorhexidine chip in the treatment of periodontitis: a multicenter study. $J$ Periodontol. 2008;79:271-82.

24. Paolantonio M, Dolci M, Perfetti G, Sammartino G, D'Archivio D, Spoto G Ciampoli C, De Amicis D, Tete S. Effect of a subgingival chlorhexidine chip on the clinical parameters and the levels of alkaline phosphatase activity in gingival crevicular fluid during the non-surgical treatment of periodontitis. J Biol Regul Homeost Agents. 2008;22:63-72.

25. Cosyn J, Wyn I, De Rouck T, Sabzevar MM. Subgingival chlorhexidine varnish administration as an adjunct to same-day full-mouth root planing. I. Clinical observations. J Periodontol. 2007:78:430-7.

26. Denez EM, Toma S, Lasserre JF, Brecx MC. Evaluation of a unique subgingival irrigation with $10 \%$ povidone-iodine after scaling and root planing: a randomized clinical trial. Quintessence Int. 2016;47:549-58.

27. Azmak N, Atilla G, Luoto H, Sorsa T. The effect of subgingival controlledrelease delivery of chlorhexidine chip on clinical parameters and matrix metalloproteinase-8 levels in gingival crevicular fluid. J Periodontol. 2002;73: 608-15.

28. Kruck C, Eick S, Knofler GU, Purschwitz RE, Jentsch HF. Clinical and microbiologic results 12 months after scaling and root planing with different irrigation solutions in patients with moderate chronic periodontitis: a pilot randomized trial. J Periodontol. 2012;83:312-20.

29. Matesanz-Perez P, Garcia-Gargallo M, Figuero E, Bascones-Martinez A, Sanz M, Herrera D. A systematic review on the effects of local antimicrobials as adjuncts to subgingival debridement, compared with subgingival debridement alone, in the treatment of chronic periodontitis. J Clin Periodontol. 2013;40:227-41

30. Paraskevas S, Huizinga JD, Loos BG. A systematic review and meta-analyses on C-reactive protein in relation to periodontitis. J Clin Periodontol. 2008;35: 277-90.

31. Higgins JP, Altman DG, Gotzsche PC, Juni P, Moher D, Oxman AD, Savovic J, Schulz KF, Weeks L, Sterne JA. Cochrane Bias methods group, Cochrane Statistical Methods Group The cochrane collaboration's tool for assessing risk of bias in randomised trials. BMJ. 2011;343:d5928.

32. DerSimonian R, Kacker R. Random-effects model for meta-analysis of clinical trials: an update. Contemp Clin Trials. 2007;28:105-14.

33. Saglam M, Arslan U, Buket Bozkurt S, Hakki SS. Boric acid irrigation as an adjunct to mechanical periodontal therapy in patients with chronic periodontitis: a randomized clinical trial. J Periodontol. 2013;84:1297-308.

34. Zanatta GM, Bittencourt S, Nociti FH Jr, Sallum EA, Sallum AW, Casati MZ. Periodontal debridement with povidone-iodine in periodontal treatment: short-term clinical and biochemical observations. J Periodontol. 2006;77: 498-505.

35. Cosyn J, Wyn I, De Rouck T, Moradi SM. Clinical benefits of subgingival chlorhexidine varnish application as an adjunct to same-day full-mouth root planing: a pilot study. J Periodontol. 2006;77:1074-9.

36. John P, Lazarus F, George JP, Selvam A, Prabhuji ML. Adjunctive effects of a piscean collagen-based controlled-release chlorhexidine chip in the treatment of chronic periodontitis: a clinical and microbiological study. J Clin Diagn Res. 2015;9:ZC70-4.

37. Gupta R, Pandit N, Aggarwal S, Verma A. Comparative evaluation of subgingivally delivered $10 \%$ doxycycline hyclate and xanthan-based chlorhexidine gels in the treatment of chronic periodontitis. J Contemp Dent Pract. 2008;9:25-32.

38. Lecic J, Cakic S, Janjic Pavlovic O, Cicmil A, Vukotic O, Petrovic V, Cicmil S. Different methods for subgingival application of chlorhexidine in the treatment of patients with chronic periodontitis. Acta Odontol Scand. 2016; 74:502-7.

39. Medaiah S, Srinivas M, Melath A, Girish S, Polepalle T, Dasari AB Chlorhexidine chip in the treatment of chronic periodontitis - a clinical study. J Clin Diagn Res. 2014;8:ZC22-5.

40. Gonzales JR, Harnack L, Schmitt-Corsitto G, Boedeker RH, Chakraborty T, Domann E, Meyle J. A novel approach to the use of subgingival controlledrelease chlorhexidine delivery in chronic periodontitis: a randomized clinical trial. J Periodontol. 2011:82:1131-9.

41. Grisi DC, Salvador SL, Figueiredo LC, Souza SL, Novaes AB, Grisi MF. Effect of a controlled-release chlorhexidine chip on clinical and microbiological parameters of periodontal syndrome. J Clin Periodontol. 2002;29:875-81.

42. Mizrak T, Guncu GN, Caglayan F, Balci TA, Aktar GS, Ipek F. Effect of a controlled-release chlorhexidine chip on clinical and microbiological parameters and prostaglandin E2 levels in gingival crevicular fluid. J Periodontol. 2006;77:437-43.

43. Machtei EE, Hirsh I, Falah M, Shoshani E, Avramoff A, Penhasi A. Multiple applications of flurbiprofen and chlorhexidine chips in patients with chronic periodontitis: a randomized, double blind, parallel, 2-arms clinical trial. J Clin Periodontol. 2011;38:1037-43. 
44. Vitt A, Gustafsson A, Ramberg P, Slizen V, Kazeko LA, Buhlin K. Polyhexamethylene guanidine phosphate irrigation as an adjunctive to scaling and root planing in the treatment of chronic periodontitis. Acta Odontol Scand. 2019:1-6.

45. Rosling B, Hellstrom MK, Ramberg P, Socransky SS, Lindhe J. The use of PVPiodine as an adjunct to non-surgical treatment of chronic periodontitis. J Clin Periodontol. 2001;28:1023-31.

46. Kasaj A, Chiriachide A, Willershausen B. The adjunctive use of a controlledrelease chlorhexidine chip following treatment with a new ultrasonic device in supportive periodontal therapy: a prospective, controlled clinical study. Int J Dent Hyg. 2007:5:225-31.

47. Leonhardt A, Bergstrom C, Krok L, Cardaropoli G. Healing following ultrasonic debridement and PVP-iodine in individuals with severe chronic periodontal disease: a randomized, controlled clinical study. Acta Odontol Scand. 2006:64:262-6.

48. Bonito AJ, Lux L, Lohr KN. Impact of local adjuncts to scaling and root planing in periodontal disease therapy: a systematic review. J Periodontol. 2005;76:1227-36.

49. Smiley CJ, Tracy SL, Abt E, Michalowicz BS, John MT, Gunsolley J, Cobb CM, Rossmann J, Harrel SK, Forrest JL, Hujoel PP, Noraian KW, Greenwell H, Frantsve-Hawley J, Estrich C, Hanson N. Systematic review and meta-analysis on the nonsurgical treatment of chronic periodontitis by means of scaling and root planing with or without adjuncts. J Am Dent Assoc. 2015;146:50824.e5.

50. Hanes PJ, Purvis JP. Local anti-infective therapy: pharmacological agents. A systematic review. Ann Periodontol. 2003:8:79-98.

51. Salvi GE, Mombelli A, Mayfield L, Rutar A, Suvan J, Garrett S, Lang NP. Loca antimicrobial therapy after initial periodontal treatment. J Clin Periodontol. 2002;29:540-50

\section{Publisher's Note}

Springer Nature remains neutral with regard to jurisdictional claims in published maps and institutional affiliations.

Ready to submit your research? Choose BMC and benefit from:

- fast, convenient online submission

- thorough peer review by experienced researchers in your field

- rapid publication on acceptance

- support for research data, including large and complex data types

- gold Open Access which fosters wider collaboration and increased citations

- maximum visibility for your research: over $100 \mathrm{M}$ website views per year

At $\mathrm{BMC}$, research is always in progress.

Learn more biomedcentral.com/submissions 